\title{
The social environment and neurogenesis in the adult mammalian brain
}

\section{Claudia Lieberwirth* and Zuoxin Wang}

Program in Neuroscience, Department of Psychology, Florida State University, Tallahassee, FL, USA

\author{
Edited by: \\ Ulrich Pfeiffer, University Hospital \\ Cologne, Germany \\ Reviewed by: \\ Bruce S. Cushing, The University of \\ Akron, USA \\ Melissa Holmes, University of Toronto \\ Mississauga, Canada

\section{*Correspondence:} \\ Claudia Lieberwirth, Program in \\ Neuroscience, Department of \\ Psychology, Florida State University, \\ 1107 West Call Street, Tallahassee, FL \\ 32306, USA. \\ e-mail: lieberwirth@neuro.fsu.edu
}

\begin{abstract}
Adult neurogenesis - the formation of new neurons in adulthood - has been shown to be modulated by a variety of endogenous (e.g., trophic factors, neurotransmitters, and hormones) as well as exogenous (e.g., physical activity and environmental complexity) factors. Research on exogenous regulators of adult neurogenesis has focused primarily on the non-social environment. More recently, however, evidence has emerged suggesting that the social environment can also affect adult neurogenesis. The present review details the effects of adult-adult (e.g., mating and chemosensory interactions) and adult-offspring (e.g., gestation, parenthood, and exposure to offspring) interactions on adult neurogenesis. In addition, the effects of a stressful social environment (e.g., lack of social support and dominant-subordinate interactions) on adult neurogenesis are reviewed. The underlying hormonal mechanisms and potential functional significance of adult-generated neurons in mediating social behaviors are also discussed.
\end{abstract}

Keywords: adult neurogenesis, social behavior, amygdala, hippocampus, hypothalamus, olfactory bulb

\section{INTRODUCTION}

Social interactions among conspecifics, such as adult-adult and adult-offspring interactions, are an integral part of human society and affect psychological, physiological, and behavioral functions. Indeed, enduring and selective sociosexual attachments between partners are an intrinsic part of human social behavior. The formation and maintenance of such strong social bonds are critical for both mental and physical health. For example, individuals in a stable marital relationship display a longer life expectancy than individuals who are single (House et al., 1988; Lillard and Waite, 1995). Further, high levels of intimacy between partners are positively correlated with immune function and cardiovascular health; whereas low levels of intimacy are correlated with negative psychological states, such as depressed mood (Waltz et al., 1988; Kiecolt-Glaser and Newton, 2001). Close parent-child relationships (through bi-parental care) lead to the physical as well as psychological well-being of both parents and their children (Silverstein and Bengtson, 1991; Graziano et al., 2009). Furthermore, strong adult-adult and adult-offspring interactions also play a protective role on the vulnerability to substance abuse (Ellickson et al., 1999; Bell et al., 2000). Social connectedness, defined as internal sense of social belonging, reduces the likelihood of experiencing anxiety and is a protective factor against depression (Lee and Robbins, 1998; Townsend and McWhirter, 2005). In contrast, negative social interactions, such as disruptions of social bonds, confrontation, isolation, or neglect, can cause psychosocial stress,

Abbreviations: ${ }^{3} \mathrm{H}$, tritiated thymidine; AMY, amygdala; $\mathrm{AOB}$, accessory olfactory bulb; BrdU, bromodeoxyuridine; Dcx, doublecortin; DG, dentate gyrus; HYP, hypothalamus; MCM-2, minichromosome marker-2; MOB, main olfactory bulb; MPOA, medial preoptic area; NeuN, neuronal nuclei; NSE, neuron-specific enolase; PCNA, proliferating cell nuclear antigen; PFC, prefrontal cortex; SVZ, subventricular zone; TMT, trimethyl thiazoline. posing a risk to mental and physical health (Steptoe, 1991; Curtis, 1995). In addition, the lack of social interactions leading to feelings of loneliness has been correlated with the experience of depression (Alpass and Neville, 2003; Adams et al., 2004), further highlighting the importance of social interactions. Finally, the inability to form social bonds is often used to diagnose psychological disorders, including autism, social anxiety, and schizophrenia (Hersen, 2006).

Similar to the importance of social interactions in humans, adult-adult and adult-offspring interactions also affect physiological and behavioral functions in other mammalian species. For example, prior sexual experience improves subsequent mating behavior in both male and female rats and 18-24h of sociosexual interactions between a male and female are sufficient to lead to a pair bond - the selective, enduring preferential attachment between a mating pair - in the socially monogamous prairie vole (Microtus ochrogaster; Dewsbury, 1975; Williams et al., 1992; Meisel and Mullins, 2006; Hull and Rodriguez-Manzo, 2009). Furthermore, mother-offspring bonds are formed in a variety of mammalian species in response to interactions with offspring (see reviews by Nowak et al., 2000; Maestripieri, 2001; Mogi et al., 2011). Subsequently, this type of social bond leads to adaptive behavioral changes that maintain offspring proximity and enhance mother-offspring interactions, thereby increasing the likelihood of offspring survival as well as parents' reproductive success (Winberg, 2005). Animal models have been utilized to study the effects of social interactions on the brain, particularly on neuronal activation, morphology, and neurotransmitter system activity as well as the roles of social interactions on the regulation of biobehavioral functions. For instance, male-female sociosexual interactions alter the dendritic morphology in selected brain areas in rats (Flanagan-Cato et al., 2006). In prairie voles, mating-induced pair bonds are associated with neuroplastic changes in several 
neurotransmitter systems including dopamine, oxytocin, and arginine vasopressin, which in turn play important roles in social behaviors such as enduring bonds between mates, selective aggression against novel conspecifics, and enhanced parental care toward offspring (reviewed in Young and Wang, 2004; Young et al., 2011). Recent studies have also shown that social interactions affect neurogenesis in the adult brain in a variety of mammalian species (see below).

\section{NEUROGENESIS IN THE ADULT BRAIN}

Neurogenesis, progenitor cell division leading to functionally integrated neurons, was traditionally believed to only occur in the developing brain (Ramon y Cajal, 1928). However, over the past decades the use of new detection methods resulted in the accumulation of a substantial amount of evidence for the occurrence of neurogenesis throughout adulthood in a variety of mammalian species (Gross, 2000). These new detection methods include the discovery of endogenous cell cycle markers as well as the development of exogenous cell division markers including genetic tools (e.g., viral vector) and nucleotide analogs (Ming and Song, 2005). Endogenous cell cycle markers (see Table 1) include nuclear antigens expressed only in actively dividing cells (namely during the $G_{1}, S$, and $G_{2}$ phases of the cell division cycle and during mitosis) and can therefore be used as proliferation markers. Ki67 (Scholzen and Gerdes, 2000; Kee et al., 2002), proliferating cell nuclear antigen (PCNA; Galand and Degraef, 1989; but also see Properi, 1997), minichromosome marker-2 (MCM-2; Stoeber et al., 2001) as well as the expression of phosphorylated histone H3 (Gurley et al., 1974) are commonly used endogenous cell cycle markers. Studying adult neurogenesis using viral vectors (such as retroviruses) requires invasive stereotaxic surgery to inject the viral vector into specific brain regions. As viral vector integration is dependent on nuclear membrane breakdown during mitosis, expression of the viral vector is a good indicator of cell division. Retroviruses are usually non-replicative (to limit viral vector expression to cells that integrated the vector during mitosis) and carry a reporter gene, such as green fluorescent protein (to allow easy identification of cells expressing the retrovirus). Lastly, nucleotide analogs such as tritiated thymidine $\left({ }^{3} \mathrm{H}\right)$ and bromodeoxyuridine (BrdU) are exogenous cell cycle markers. After their administration (usually via intraperitoneal injection), they are incorporated into the DNA in place of thymidine during the DNA synthesis phase of the cell cycle. Subsequently, labeled cells can be revealed by autoradiography (for ${ }^{3} \mathrm{H}$ ) or immunohistochemistry (for BrdU). While both markers are similar in their efficiency to label dividing cells, BrdU has several advantages (e.g., non-isotopic method, lower cost, and shorter tissue processing duration) over ${ }^{3} \mathrm{H}$ and, therefore, has become the more commonly used nucleotide analog. Depending on the experimental paradigm (i.e., BrdU injection mode and the time interval between

Table 1 | Commonly used methods to study adult neurogenesis.

\begin{tabular}{|c|c|c|c|c|}
\hline Method & Example & Expression pattern & Application & Reference \\
\hline \multirow{3}{*}{$\begin{array}{l}\text { NUCLEOTIDE } \\
\text { ANALOG }\end{array}$} & Tritiated thymidine $\left({ }^{3} \mathrm{H}\right)$ & Nucleus & Proliferation, survival & Cameron and McKay \\
\hline & & & & $(2001)$ \\
\hline & Bromodeoxyuridine (BrdU) & Nucleus & $\begin{array}{l}\text { Proliferation, survival, fate } \\
\text { determination }\end{array}$ & $\begin{array}{l}\text { Cameron and McKay } \\
\text { (2001) }\end{array}$ \\
\hline \multirow{5}{*}{$\begin{array}{l}\text { ENDOGENOUS CELL } \\
\text { CYCLE MARKER }\end{array}$} & Ki67 & Nucleus & Proliferation & Scholzen and Gerdes \\
\hline & & & & (2000), Kee et al. (2002) \\
\hline & Minichromosome marker-2 (MCM-2) & Nucleus & Proliferation & Stoeber et al. (2001) \\
\hline & Phosphorylated histone $\mathrm{H} 3$ & Nucleus & Proliferation & Gurley et al. (1974) \\
\hline & Proliferating cell nuclear antigen (PCNA) & Nucleus & Proliferation & $\begin{array}{l}\text { Galand and Degraef } \\
\text { (1989) }\end{array}$ \\
\hline
\end{tabular}

\section{CELLTYPE-SPECIFIC MARKER}

(a) Immature neuron

Doublecortin (Dcx)

Neuron-specific class III tubulin (TuJ1)

Polysialylated-neuronal cell adhesion

molecule (PSA-NCAM)

RNA-binding protein $\mathrm{Hu}$

Turned on after division (TOAD64/CRMP4)

(b) Mature neuron

Microtubule-associated protein (MAP-2)

Neuron-specific enolase (NSE)

Neuronal specific nuclear protein (NeuN)

(c) Glial cell

VIRAL VECTOR
Glial fibrillary acidic protein (GFAP)
Soma, cell processes

Cytoplasm, axons

Plasma membrane

Nucleus, cytoplasm

Cytoplasm

Cytoplasm, soma,

dendrites

Cytoplasm

Nucleus

Astrocytes

Soma, cell processes
Fate determination

Fate determination

Fate determination

Fate determination

Fate determination

Fate determination

Fate determination

Fate determination

Fate determination

Morphology, physiology,

fate determination
Francis et al. (1999)

Memberg and Hall (1995)

Seki and Arai (1993)

Okano and Darnell (1997)

Minturn et al. (1995)

Huber and Matus (1984)

Schmechel et al. (1980)

Mullen et al. (1992)

Eng et al. (2000)

van Praag et al. (2002) 
the last injection and perfusion), different stages of adult neurogenesis (namely cell proliferation, neuronal differentiation, and cell survival) can be investigated. For example, a single acute BrdU injection combined with a short interval between the injection and perfusion of the animal (usually 2-24h) allows the detection of cell proliferation (division of progenitor cells), similar to using endogenous cell cycle markers (see above); whereas repeated BrdU injections and longer survival times are used to study neuronal differentiation (selection of neuronal fate) and cell survival (maintenance of new neurons). Fluorescent BrdU-labeling can be combined with cell type-specific markers to determine neuronal or glial differentiation (see Table 1 for commonly used markers).

In most mammalian species (Huang et al., 1998; Dayer et al., 2005; Fowler et al., 2005; Luzzati et al., 2006), including humans (Eriksson et al., 1998), adult neurogenesis occurs primarily in two brain regions, namely the subventricular zone (SVZ) of the rostral lateral ventricle and the dentate gyrus (DG) of the hippocampus. From their site of origin, the newly generated cells migrate to the main olfactory bulb (MOB, along the rostral migratory stream) and to the hippocampal granular cell layer, respectively, where most cells differentiate into neurons and functionally integrate into the existing circuitry (Lledo and Saghatelyan, 2005; Ming and Song, 2005; Christie and Cameron, 2006). Adult neurogenesis has also been documented in other, non-traditional neurogenic brain regions (for review see Gould, 2007; Migaud et al., 2010). While there still is debate about the existence of adult neurogenesis outside the DG and SVZ/MOB system, several studies reported adult-generated neurons in the neocortex (Dayer et al., 2005), piriform cortex (Bernier et al., 2002), striatum (Bedard and Parent, 2004), amygdala (AMY; Bernier et al., 2002; Fowler et al., 2002; Akbari et al., 2007; Okuda et al., 2009), medial preoptic area (MPOA; Akbari et al., 2007), and hypothalamus (HYP; Huang et al., 1998; Fowler et al., 2002; Kokoeva et al., 2005).

A variety of endogenous (e.g., trophic factors, neurotransmitters, and hormones) and exogenous non-social (e.g., enriched environment and physical activity) factors have been shown to affect adult neurogenesis in both traditional as well as nontraditional neurogenic brain regions (Grote and Hannan, 2007; Fowler et al., 2008; Lucassen et al., 2010). Importantly, recent studies have shown that even the social environment can modulate adult neurogenesis in a stimulus- and site-specific manner (reviewed by Gheusi et al., 2009). For example, social stressors, such as the exposure to an aggressive conspecific or social isolation, reduce (Gould et al., 1997; Westenbroek et al., 2004; Czeh et al., 2007; Thomas et al., 2007; Lieberwirth et al., 2012), whereas social stimuli, such as the exposure to male pheromones, maternal experience, or interactions with a conspecific pup, increase (Furuta and Bridges, 2005; Mak et al., 2007; Ruscio et al., 2008) hippocampal adult neurogenesis.

In the following review, we will describe the effects of the social environment on mammalian adult neurogenesis by focusing on the effects of sociosexual adult-adult interactions (including mating and chemosensory interactions), adult-offspring interactions (including parenthood and exposure to unrelated conspecific young), and aversive, stressful social interactions (including social isolation, social defeat, and predator odor exposure). In addition, the potential hormonal mechanism(s) for the modulation of adult neurogenesis via social interactions will be discussed. Finally, our discussion will also summarize the evidence for adult neurogenesis in humans and discuss evidence that human adult neurogenesis can be modulated by distinct factors - highlighting the need for future studies on the potential link between social interactions and adult neurogenesis.

\section{EFFECTS OF SOCIOSEXUAL ADULT-ADULT INTERACTIONS ON ADULT NEUROGENESIS MALE-FEMALE INTERACTIONS: MATING AND REPRODUCTIVE BEHAVIOR}

Male-female interactions, particularly mating and reproductive behavior, activate several distinct brain regions in a variety of mammalian species, including humans, and influence brain plasticity (Mas, 1995; Kollack-Walker and Newman, 1997; Pfaus and Heeb, 1997; Seeringer et al., 2010). For example, neuroplastic changes induced by male-female interactions include alterations in neuronal activation, neurotransmitter release, receptor distribution, as well as neuronal morphology (Pfaus and Heeb, 1997; Flanagan-Cato et al., 2006; Veenema and Neumann, 2008; Leuner et al., 2010b). Recently, research has started to focus on evaluating the potential effect of adult-adult interactions on neurogenesis. Here, we will focus on the effects of acute and chronic sociosexual interactions on the different stages of adult neurogenesis in distinct brain regions.

The effect of acute mating encounters on adult neurogenesis has been investigated in rodents, such as rats and prairie voles, as well as in sheep. Thirty minutes of interaction with a receptive female promoted hippocampal cell proliferation in young, adult (older than 60 days of age) male Sprague-Dawley rats (Leuner et al., 2010b). These males were injected with BrdU 30 min after the first mating bout followed by a 2 -h post-injection survival period. Males with mating experience showed an increase in the number of BrdU- and Ki67-labeled cells in the DG compared to sexually naïve males, indicating that acute mating exposure upregulated hippocampal cell proliferation in adult male rats. Acute sociosexual interactions also promoted hippocampal cell proliferation in middle-aged male Sprague-Dawley rats (9-11 months of age; Glasper and Gould, 2010). However, it should be noted that neither study examined whether chemosensory cues, present during sociosexual interactions, play a role in the observed facilitation of cell proliferation. The addition of a male group exposed only to female odor cues, e.g., female-soiled bedding, would have allowed the investigation of the effect of chemosensory cues on adult neurogenesis in the absence of sociosexual interactions. In female Wistar rats, a 30-min sociosexual encounter facilitated the survival of newly proliferated cells in the olfactory system in a region-specific manner (Corona et al., 2011). Cell survival in the internal cell layer of the accessory olfactory bulb (AOB), but not the glomerular or external cellular layer of the $\mathrm{AOB}$ or the glomerular, mitral, and granular cell layer of the MOB, was upregulated 2 weeks after an acute 1-h sociosexual encounter. Within the same paradigm, the majority of adult-generated cells facilitated by the sociosexual experience expressed a mature neuronal phenotype (BrdU/NeuN double-labeled cells). Most interestingly, this increase in neuronal survival was only observed in females that experienced paced mating (pattern of approach and withdrawal in 
which the female controls the timing of sexual interactions), but not in females with non-paced mating (timing of sexual interactions is controlled by the male). The differential effects of paced versus non-paced mating on adult neurogenesis may be due to differences in their hedonic value: paced mating is rewarding and not stressful, while non-paced mating is stressful (Martinez and Paredes, 2001; Nyuyki et al., 2011). In addition, paced mating has been found to optimize the reproductive physiology and behavior in females, leading to enhanced reproductive success and fitness (Erskine and Kornberg, 1992). Furthermore, acute sociosexual interactions (characterized by non-paced mating) did not promote cell proliferation in female prairie voles (Fowler et al., 2002), suggesting that the hedonic value of the sociosexual interaction may play a role in the modulation of adult neurogenesis. Lastly, the exposure to a male significantly increased cell proliferation region-specifically in female Merino sheep (Hawken et al., 2009). In particular, $48 \mathrm{~h}$ of male exposure increased hippocampal, but not hypothalamic, cell proliferation. The importance of paced mating and the involvement of chemosensory cues in modulating cell proliferation or cell survival in sheep are not currently known. Together, these data suggest that acute sociosexual interactions, in particular rewarding interactions, may facilitate cell proliferation and/or survival in a species- and brain region-specific manner.

Chronic sociosexual interactions have also been found to modulate adult neurogenesis. Repeated daily 30 -min exposures to a receptive female for 14 consecutive days promoted hippocampal cell proliferation in young adult male Sprague-Dawley rats, compared to sexually naïve males (Leuner et al., 2010b). Two weeks following the last mating exposure, the survival of newly generated cells was also increased in the DG, while the percentage of cells expressing a neuronal phenotype (BrdU/TuJ1 and BrdU/NeuN double-labeled cells) did not differ between the groups (Leuner et al., 2010b), suggesting that chronic mating exposure facilitates adult neurogenesis. Similarly, chronic sociosexual experiences (daily 30 -min exposures for 28 consecutive days) also facilitated cell proliferation and survival in the DG of middleaged (9-11 months of age) male Sprague-Dawley rats (Glasper and Gould, 2010). However, it should be noted that neither study (Glasper and Gould, 2010; Leuner et al., 2010b) examined the role of chemosensory cues, present during sociosexual interactions, on the observed facilitation of cell proliferation. Chronic, continuous sociosexual interactions with a male for 21 consecutive days affected adult neurogenesis in female prairie voles (Fowler et al., 2002). Females were either placed with an unrelated intact male (sociosexual interaction) or an unrelated female (control condition). BrdU injections were given $24 \mathrm{~h}$ following the placement into the respective treatment condition. Short-term chronic sociosexual interactions ( 21 days) increased the number of BrdUlabeled cells in the AMY (in particular the cortical nucleus) and the ventromedial hypothalamus $(\mathrm{VMH})$, without affecting the number of BrdU-labeled cells in the DG, MOB, cingulate cortex, or caudate putamen - indicating that the effects of chronic sociosexual interactions on cell survival are brain region-specific. It should be noted that the observed changes in cell survival could be due to different components of the chronic sociosexual interactions with the male. In particular, 21 days of sociosexual interactions in female prairie voles result in both pair bond formation and pregnancy, which could have differential or synergistic effects on adult neurogenesis. Furthermore, the exposure to only male chemosensory cues, without mating, may also play a role in mediating adult neurogenesis. In another socially monogamous rodent species, the mound-building mouse (Mus spicilegus), successful pair bond formation induced by chronic sociosexual interactions (20-day cohabitation) resulted in a higher number of BrdU-labeled cells in the MOB of these females compared to females that did not show a partner preference (an index of an established pair bond in the laboratory) after chronic sociosexual interactions with a male (Baudoin et al., 2005). Interestingly, sub-chronic sociosexual interactions did not facilitate hippocampal cell proliferation. In particular, male Long-Evans rats exposed to a receptive female for $30 \mathrm{~min}$ on five consecutive days did not differ in the level of cell proliferation from sexually naïve males (Spritzer et al., 2009). Similar to sub-chronic mating, intermittent mating (weekly sociosexual interactions with a receptive female over seven consecutive weeks) did not affect adult neurogenesis in the mating circuit (namely the MPOA and medial AMY) of Syrian hamsters (Mesocricetus auratus; Antzoulatos et al., 2008). It should be noted, however, that the effects of intermittent mating on hippocampal adult neurogenesis, the effect of chronic daily sociosexual interactions on adult neurogenesis in the mating circuitry or the DG, or the effect of chemosensory cues without mating on adult neurogenesis were not evaluated in the above mentioned studies.

Unfortunately, the majority of the studies investigating the effects of sociosexual encounters on adult neurogenesis did not control directly for the effects of chemosensory cues, cues that are present during mating. Nonetheless, there is evidence suggesting that sociosexual interactions may modulate adult neurogenesis independent from chemosensory cues. For example, paced mating resulted in the upregulation of adult neurogenesis compared to non-paced mating or chemosensory exposure (Corona et al., 2011). Overall, future research may benefit from investigating specifically whether both acute and chronic mating exposures independent of chemosensory cues affect adult neurogenesis in various mammalian species. Based on the currently available data, acute and chronic mating seem to facilitate hippocampal cell proliferation and chronic mating seems to facilitate cell survival in several distinct brain regions, including the AMY, DG, OB, and $\mathrm{VMH}$. Interestingly, these brain regions, in particular the AMY, $\mathrm{MOB}$, and $\mathrm{VMH}$, are part of the mating circuitry. Therefore, future studies should investigate the functional involvement of adultgenerated neurons in these brain regions in the modulation of mating behavior. Furthermore, additional studies should evaluate the involvement of adult-generated neurons in the modulation of the stress response and anxiety. In particular, the AMY, part of the stress circuitry (Jankord and Herman, 2008), has been implicated in mediating mating-induced anxiolysis (Waldherr and Neumann, 2007).

\section{CHEMOSENSORY CUES AFFECT ADULT NEUROGENESIS}

Chemosensory cues, consisting of odorants (volatile olfactory cues) and pheromones (non-volatile chemicals), are processed via the main olfactory and vomeronasal systems (Tirindelli et al., 2009). Traditionally, pheromones have been described to relay 
information about the sex, social status, and health of conspecifics (Ganem et al., 2005; Kavaliers et al., 2005), and thereby influence behavioral responses in most mammalian species (Brennan, 2010). For example, pheromones are involved in modulating rodent mating and reproductive behaviors (Dulac and Torello, 2003; Brennan and Keverne, 2004) and also play a role in human social behavior, such as attraction (Cowley and Brooksbank, 1991). In addition, evidence has emerged suggesting that volatile olfactory cues may also communicate social cues and thereby influence social behavior (Lin et al., 2005).

As chemosensory cues play an important role in social behaviors, which have been shown to affect adult neurogenesis, acute, and chronic exposure to conspecific chemosensory cues have been investigated for their role in modulating adult neurogenesis. For example, acute exposure to chemosensory cues increased cell proliferation in the SVZ of female prairie voles (Smith et al., 2001). Specifically, female prairie voles exposed to a male across a mesh barrier (mesh-housing), allowing olfactory and visual, but not physical contact, for $48 \mathrm{~h}$ had a greater number of BrdU-labeled cells in the SVZ compared to females exposed to a female across a mesh barrier. Recent data indicated that chemosensory cues also affect cell proliferation in the prairie vole AMY in a sexspecific manner (Liu et al., 2007). In particular, $48 \mathrm{~h}$ of exposure to opposite-sex bedding caused a significant increase in amygdalar cell proliferation in female, but not male, prairie voles compared to voles that were exposed to their own bedding or to the bedding from a same-sex individual. Analysis of the AMY subnuclei indicated that this increase was present in the cortical and medial, but not the central, subnuclei. It should be noted that lesions of either the MOB or the vomeronasal organ were sufficient to block this chemosignal-induced increase in cell proliferation. In contrast, $48 \mathrm{~h}$ of chemosensory exposure in female CD-1 mice did not affect adult neurogenesis in the SVZ or the DG (Mak et al., 2007). While species-specific differences may explain the lack of an effect of chemosensory cues on cell proliferation in the SVZ of female mice, the two studies differed significantly in their methodology. For example, the chemosensory experience may differ significantly between mesh-housing as used in the female prairie vole study and 2-day exposure to male-soiled bedding as used in the female mouse study (Liu et al., 2007; Mak et al., 2007). Furthermore, the effects of acute chemosensory modulation of adult neurogenesis may ameliorate a stress-induced decrease in cell proliferation. Adult male Balb/C mice showed a significant reduction in hippocampal cell proliferation following $30 \mathrm{~min}$ of restraint stress, while the presence of either familiar or unfamiliar conspecifics (without physical interaction) or conspecific odors alone reversed this stress-induced decrease in cell proliferation (Cherng et al., 2011). The number of cells expressing a neuronal phenotype (BrdU/Dcx co-labeled cells) showed the same reversal of this stress-induced decrease due to the presence of conspecifics or conspecific odors.

Chronic exposure to social chemosensory cues also modulates adult neurogenesis. In one study, adult female CD-1 mice in proestrus were exposed to male-soiled bedding, volatiles derived from male-soiled bedding, or clean bedding daily for 30 consecutive days (Oboti et al., 2009). Exposure to male-soiled bedding led to a significant increase in cell survival in the AOB, but not the MOB, compared to the volatile and clean bedding groups.
Sub-chronic exposure to male chemosensory cues also promoted cell proliferation in pregnant mice (Larsen et al., 2008); however, this effect was dependent on the length of exposure. Mated nulliparous female C57BL/6J mice exposed to male chemosensory cues via mesh-housing showed a higher number of BrdU-labeled cells in the SVZ compared to single-housed mated nulliparous females after 7 days, but not 3 or 14 days, of male chemosensory exposure. In addition to the increase in cell proliferation in the SVZ, 7-day chemosignal exposure also increased the number of BrdU-labeled cells and cells expressing a neuronal phenotype (cells doublelabeled for BrdU/NeuN or BrdU/Dcx) in the MOB (Larsen et al., 2008). Sub-chronic chemosensory exposure (7 consecutive days of male-soiled bedding exposure) also facilitated DG and SVZ cell proliferation as well as cell survival and neuronal differentiation in the DG and MOB in sexually naïve female mice (Mak et al., 2007). It should be noted that the chemosensory cue induced changes of adult neurogenesis required the $\mathrm{MOB}$, as chemical lesions of the MOB prevented such changes (Mak et al., 2007). Furthermore, the social status of the male from which the chemosensory cues were obtained also played a role in mediating adult neurogenesis in the female mouse brain (Mak et al., 2007). In particular, the number of BrdU-labeled cells was only increased when females were exposed to dominant-male, but not subordinate-male, chemosensory cues, possibly highlighting a link between adult neurogenesis and social behavior.

Together, these data demonstrate that exposure to chemosensory cues facilitates cell proliferation and cell survival in the adult brain in a stimulus-, brain region-, and sex-specific manner. As facilitation of adult neurogenesis was also observed in response to sociosexual interactions, future studies are needed to investigate the function of new neurons, which are generated in response to mating and mating-related interactions.

\section{EFFECT OF ADULT-OFFSPRING INTERACTIONS ON ADULT NEUROGENESIS GESTATION}

Gestation leads to dramatic changes in circulating levels of hormones (including increased levels of progesterone, estrogen, and prolactin) in females (Garland et al., 1987; Pawluski et al., 2009). Furthermore, gestation causes significant neuroanatomical alterations (e.g., increases in spine density; Rasia-Filho et al., 2004) and neurochemical alterations (e.g., central receptor-level upregulation; Grattan, 2001; Russell et al., 2001; Kinsley et al., 2006). Similarly, pregnancy causes dramatic changes in humans such as changes in circulating hormone levels (including progesterone, estrogen, and leptin; Turnbull et al., 1974; Sivan et al., 1998). In addition, the absolute brain size in humans decreases across pregnancy but returns to preconception size after delivery (Oatridge et al., 2002), implicating alterations in cell birth and death as well as in cell volumes.

Early evidence suggesting that gestation may affect adult neurogenesis comes from a study in meadow voles (Microtus pennsylvanicus) that were wild-captured either during the breeding or non-breeding season (Galea and McEwen, 1999). Following capture, voles were injected with ${ }^{3} \mathrm{H}$ and perfused $24 \mathrm{~h}$ thereafter to determine the level of adult hippocampal cell proliferation. Females captured during the breeding season showed a significant 
reduction in ${ }^{3} \mathrm{H}$-labeled cells in the granular cell layer and hilus of the DG compared to females captured during the non-breeding season. As only the females captured during the breeding season were pregnant, these data suggest that gestation could impair adult neurogenesis.

Studies using natural populations of animals often exhibit difficult to control variables (e.g., length of gestation, animal age, and experience in addition to environmental factors) that may potentially affect adult neurogenesis. Consequently, the effects of gestation on adult neurogenesis have been studied in the laboratory, where potentially confounding variables can be controlled more easily. In female meadow voles of a laboratory-maintained population, reproductively inactive females (female-paired females) showed a greater level of hippocampal cell proliferation, particularly in the granular cell layer and hilus, than reproductively active females (male-paired females; Ormerod and Galea, 2001). In addition, the survival of adult-generated cells in the hippocampal granular cell layer was higher in reproductively inactive, compared to reproductively active, female meadow voles. Similar studies have also been conducted using other laboratory rodents. For example, cell proliferation within the subgranular zone of the DG was reduced in pregnant female $\mathrm{C} 57 \mathrm{Bl} / 6 \mathrm{~N}$ mice across all gestational days $(14.5,16.5$, and 18.5$)$ examined compared to virgin control mice (Kim et al., 2010). Further, the total number of Ki67/Dcx double-labeled cells was significantly lower within the DG of the late gestational groups (day 16.5 and 18.5) compared to virgin mice, implicating an effect on the neuronal differentiation (Dcx-expression) of newly generated cells (Ki67-labeled). Similarly, Rolls et al. (2008) showed that the number of cells expressing a neuronal phenotype (BrdU/Dcx double-labeled cells) within the murine DG was significantly reduced during both the second and third trimester compared to virgin C57BL/6 mice. Furthermore, a comparison between non-pregnant sheep and sheep at the end of the gestational period revealed a significant reduction in cell proliferation in the DG of pregnant sheep (Brus et al., 2010). Interestingly, unlike in meadow voles, mice, and sheep, gestation did not affect hippocampal cell proliferation in Sprague-Dawley rats (Furuta and Bridges, 2005). In particular, neither the early (gestational day 7) nor the late (gestational day 21) gestational stage decreased cell proliferation in rats. Furthermore, on gestational day 1, virgin (control) female rats did not differ in the rate of cell proliferation in the granule cell layer and hilus of the DG compared to primigravid (first gestation) or multigravid females, indicating that the number of pregnancies does not seem to affect adult neurogenesis in rats (Pawluski et al., 2010). Hippocampal cell survival at gestational day 21 also did not differ between virgin and pregnant females, irrespective of the number of pregnancies. Together, these data suggest that gestation may affect adult hippocampal neurogenesis in a species-specific manner.

Gestation has also been reported to affect adult neurogenesis within the SVZ/MOB. For example, in Sprague-Dawley rats, cell proliferation was increased in the SVZ on gestational day 21 , but not day 7 , indicating a time-specific effect (Furuta and Bridges, 2005). Similarly, gestation increased adult neurogenesis in the murine SVZ. The number of BrdU-labeled cells in the SVZ was higher on gestational day 7 (as well as day 7 of pseudopregnancy, following mating with a vasectomized male) relative to age-matched virgin controls, but such an effect was no longer observed on gestational day 14 (Shingo et al., 2003). The increase in BrdU-labeling was likely due to an increase in cell proliferation, as indicated by a similar increase in Ki67-labeling in the SVZ on gestational day 7. Further, mice injected with BrdU on gestational day 7 had significantly more cells labeled for BrdU or double-labeled for BrdU/NeuN in the granule and periglomerular cell layers of the MOB 4 weeks later, compared to virgin controls, indicating that increased cell proliferation in the SVZ by gestation is closely paralleled by an enhanced survival of new neurons in the MOB. Interestingly, no difference was found in the cell proliferation in the SVZ/OB between non-pregnant (control) sheep and sheep at the end of the gestational period (Brus et al., 2010).

Together, these data highlight a brain region- and speciesspecific effect of gestation on adult neurogenesis. Specifically, gestation seems to suppress hippocampal adult neurogenesis in several mammalian species, such as meadow vole, mouse, and sheep, but not rat. In contrast, gestation seems to facilitate adult neurogenesis in the SVZ/MOB system. Future studies are needed to examine whether adult neurogenesis differs across gestational stages (in particular, early versus late gestational stage) and whether gestation-induced neurons in the SVZ/MOB are involved in mediating behaviors such as parental care, e.g., by enhancing olfactory discrimination skills.

\section{PARENTHOOD}

Parenthood is characterized by dramatic changes in behaviors (e.g., from indifference or avoidance of young to care and nurturing of offspring) as well as in hormone levels, neuronal morphology, and neurochemical systems (Numan and Insel, 2003; Bridges and Bridges, 2008). For example, it has been documented that there is an increase in the level of corticosterone (Atkinson and Waddell, 1995), hippocampal spine densities, and activation of the oxytocin and vasopressin systems during the postpartum period (Caba et al., 1996; Lin et al., 2003). Recently, interest has emerged to investigate the effect of parenthood on adult neurogenesis (Leuner et al., 2010a; Levy et al., 2011).

Maternal experience has been found to negatively affect adult neurogenesis in rats in a time- and brain region-specific manner. Female Sprague-Dawley rats on postpartum day 2 and 8, but not on postpartum day 28 and post-weaning, showed a significant reduction in hippocampal cell proliferation compared to virgin rats (Leuner et al., 2007). Such reduction in cell proliferation was not observed in the SVZ. In the same study, 1-week cell survival in the DG was also reduced in postpartum females compared to virgin rats in diestrus, but such group difference was no longer evident at a 2-week survival period. Motherhood also reduced hippocampal cell survival in female California mice (Peromyscus californicus; Glasper et al., 2011). Interacting with pups for 3 weeks (from birth until weaning) significantly reduced hippocampal cell survival of mice caring for pups compared to control females whose pups were removed at birth. A study in sheep further illustrated the negative impact of motherhood on adult neurogenesis. Following $24 \mathrm{~h}$ of interaction with their lamb, ewes showed a significant reduction in cell proliferation in the SVZ compared to nulliparous ewes and ewes that only had sociosexual interactions with males (Brus et al., 2010). In addition, cell proliferation was 
reduced in the MOB and DG in ewes following parturition (independent of interaction with the lamb) compared to nulliparous ewes or ewes that had only sociosexual interactions with a male. It is of interest to note that the hormone-simulated postpartum period after a hormone-simulated pregnancy (without interaction with pups) in Long-Evans rats also caused a reduction in cell proliferation in the DG (Green and Galea, 2008). However, the number of Dcx-labeled cells (newly generated immature neurons) did not differ across groups. Unfortunately, cell survival and neuronal maturation in the DG as well as the effect of hormonestimulated pregnancy on other brain regions was not investigated. Alternatively, motherhood does not seem to affect adult neurogenesis in Yorkshire pigs (Raymond et al., 2006). In particular, the authors compared pigs in their second parity (female lactating pigs) to adult naïve ones and showed that the number of PCNA-labeled cells within the HYP was not changed due to maternal experience, possibly suggesting that the number of gestation periods plays a role in mediating the effect on adult neurogenesis. Unfortunately, other brain regions such as the DG or the SVZ/MOB were not examined in the study.

Unfortunately, there is limited knowledge about whether late gestation, characterized by drastic changes in hormones (such as a decrease in progesterone and an increase in estrogen and prolactin; Grattan and Averill, 1990; Grattan et al., 2008), affects adult neurogenesis independently from motherhood. Future studies need to be conducted to address this research area. In addition, systematic research is needed to evaluate the underlying mechanism by which motherhood affects adult neurogenesis. Some research suggests that hormonal changes (e.g., elevation of corticosterone levels) during lactation are solely responsible for the observed changes in adult neurogenesis (Leuner et al., 2007), while there is evidence to also support the notion that adult neurogenesis is affected by parturition independent of the interaction (i.e., presence versus absence of lactation) with offspring (Brus et al., 2010).

Experience with offspring also affects adult neurogenesis in fathers. For example, in a study in C57BL6 mice, paternal experience increased cell proliferation in the DG and SVZ (Mak and Weiss, 2010). Specifically, mated males were injected with BrdU and assigned to one of three paternal conditions: (1) male remained with female during gestation until parturition (minimal paternal experience), (2) male remained with female during gestation until 2 days after parturition ( $48 \mathrm{~h}$ of paternal experience), or (3) male remained with female during gestation and was housed alone for 2 days following parturition (minimal paternal experience). Quantification of both BrdU- and Ki67-labeled cells showed that cell proliferation was significantly increased in males with $48 \mathrm{~h}$ of paternal experience compared to the other two groups. Additionally, this study showed that cell proliferation was increased in both the DG and SVZ in males with parental experience for 8 days after parturition, but cell proliferation did not differ between males with or without parental experience at 10 days following birth. Furthermore, males in the paternal experience group had more Dcx-labeled cells in the DG and SVZ than the males without pup experience. Even 3 weeks after birth, males with pups still showed more BrdU/NeuN double-labeled cells in the DG and $\mathrm{OB}$ than males without pups, indicating an enhanced neuronal differentiation of the newly proliferated cells by paternal experience. Interestingly, fatherhood seems to modulate adult neurogenesis differently in monogamous species that are bi-parental. For example, in male California mice ( $P$. californicus), the number of BrdU-labeled cells in both the DG and SVZ was significantly reduced in males that interacted with pups for 21 days compared to control males without pup interactions (from birth until weaning), indicating reduced cell survival associated with paternal experience (Glasper et al., 2011). However, no group differences were found in the percentage of adult-generated cells expressing a neuronal marker, indicating that neuronal fate specification was not affected by paternal experience. In addition, recent data in the socially monogamous prairie voles indicated that fatherhood differentially affects cell proliferation and cell survival (C. Lieberwirth, unpublished data). In particular, cell proliferation (as assessed by Ki67-labeling) in the AMY, DG, and VMH did not differ between sexually naïve males and fathers. However, fathers showed a significant reduction in cell survival (as assessed by BrdU-labeling) in the AMY, DG, and VMH, but not the MOB, compared to sexually naïve males.

To conclude, parental care plays a key component in the survival of offspring and not surprisingly places considerable demands on the parent. In particular, gestation, lactation, and infant care are energetically costly to females and corticosterone levels are elevated during gestation and the postpartum period (Bronson, 1989; Atkinson and Waddell, 1995). Consequently, maternal investment may represent a stressor inhibiting adult neurogenesis similar to other stressors, such as exposure to an aggressive conspecific or social isolation (Gould et al., 1997; Czeh et al., 2007; Lieberwirth et al., 2012). As fathers in monogamous bi-parental mammals display very similar parental behaviors as females except nursing (Lonstein and De Vries, 1999), fatherhood likely also places considerable demands on fathers. Indeed, evidence suggests that there is a significant weight loss associated with paternal care in several bi-parental mammals including tamarins, lemurs, and prairie voles (Sanchez et al., 1999; Achenbach and Snowdon, 2002; Fietz and Dausmann, 2003; Campbell et al., 2009). In addition, the finding that singly living male prairie voles have a greater survival rate in the field than paired males (Getz and McGuire, 1993) provides additional evidence to support the notion that parenthood in biparental mammals places considerable demands on fathers, and thus paternal investment may be stressful and inhibit adult neurogenesis. Parenthood seems to modulate adult neurogenesis in a species-specific manner, as parenthood with potentially less investment (such as paternal care in a non-paternal species) facilitates adult neurogenesis (Mak and Weiss, 2010).

\section{INTERACTION WITH CONSPECIFIC YOUNG}

In several species, the mere exposure to neonatal unrelated conspecifics can elicit parental behavior (behavioral sensitization; Rosenblatt, 1967), which does not qualitatively differ from that seen in natural parents (with the exception of lactation; Lonstein and De Vries, 2000). Not surprisingly, the exposure to neonatal unrelated conspecifics may also affect adult neurogenesis.

In the socially monogamous male and female prairie voles, an acute (20-min) pup exposure facilitated cell proliferation in the DG, but not the AMY, indicated by a significant increase in the number of BrdU-labeled cells in the DG, compared to males and 
females which were exposed to a novel object or handled controls (Ruscio et al., 2008). In another study, female Sprague-Dawley rats were injected with BrdU, either exposed to six 1-day-old unrelated pups for $10 \mathrm{~min}$ or left alone (controls), and perfused 4 weeks later (Akbari et al., 2007). Interactions with the unrelated pups did not affect cell survival in the MOB and AOB. However, a significant increase in cell survival, indicated by more BrdU-labeled cells, was found in the nucleus accumbens core and bed nucleus of the stria terminalis, but not the AMY, following pup interactions.

Interestingly, the interactions with a conspecific pup did not affect murine adult neurogenesis when males were housed with unrelated pups. In particular, following 2-day housing with an unrelated pup no effect on cell proliferation in the DG or SVZ was observed in male C57BL6 mice (Mak and Weiss, 2010). Sexually experienced males without pup exposure did not differ in the number of BrdU-labeled cells compared to males that were exposed to an unrelated pup. Furthermore, the type of interaction (physical versus chemosensory) did not play a role as males that were allowed to freely interact with the unrelated pup did not differ from the males that were exposed to the unrelated pup behind a mesh barrier.

\section{EFFECT OF THE STRESSFUL SOCIAL ENVIRONMENT ON ADULT NEUROGENESIS}

Positive social interactions, especially interactions with deeply rooted social bonds including sexual partners and close family members, are important for an individual's well-being. In contrast, negative social interactions such as social isolation, confrontations, disruption, and social defeat are inevitable psychosocial stressors that induce a stress response, impair the function of multiple biological systems, and pose a risk to one's mental and physiological health (Steptoe, 1991; Curtis, 1995; Smith and Wang, 2011). Across most of the animal kingdom, psychosocial stress resulting from competition for space, shelter, food, water, or access to a potential mate occurs regularly. Such psychosocial stress is associated with deleterious consequences to behaviors and physiology. Here we will focus on the effects of psychosocial and psychological stressinduced by (1) lack/disruption of social bonds, (2) social defeat, and (3) predator odor exposure on adult neurogenesis.

\section{LACK OR DISRUPTION OF SOCIAL INTERACTION}

The lack or disruption of social interactions are particularly distressing and can lead to various behavioral, physiological, as well as neuronal changes (such as altering adult neurogenesis). Among the first studies to investigate the effect of social isolation on adult neurogenesis is a study in female prairie voles (Fowler et al., 2002). Acute $(48 \mathrm{~h})$ social isolation significantly increased the number of adult-generated cells in the SVZ, but did not affect cell proliferation in the other brain regions examined (i.e., AMY, DG, HYP, and cingulate cortex), compared to control females (female-female housed). In the same study, 21 days of chronic social isolation seemed to decrease the number of adult-generated cells in the AMY and HYP (without affecting the other brain regions), but such changes did not reach statistical significance, indicating a lack of effect on cell survival. The length of social isolation may play an important role in influencing adult neurogenesis. Indeed, a study in rats reported that sub-chronic ( 8 days) social isolation did not affect hippocampal cell survival, whereas short-term chronic (21 days) social isolation reduced cell survival in female, but not male, Wistar rats (Westenbroek et al., 2004). Interestingly, in a different strain of rats, short-term chronic social isolation (15 days) reduced cell survival in the hilus, but not the granular cell layer, of the DG in male Sprague-Dawley rats (Spritzer et al., 2011). The same study also reported that isolation treatment increased the number of adult-generated hippocampal cells expressing a neuronal phenotype (BrdU/NeuN double-labeled cells). The reason for this increase in neuronal differentiation with simultaneous decreases in cell survival is not known. Furthermore, long-term chronic social isolation (42 days) significantly decreased cell proliferation in the DG and MPOA, impaired cell survival in the AMY, $\mathrm{DG}$, and $\mathrm{VMH}$, and reduced neuronal differentiation (as indicated by BrdU/NeuN double-labeling) in the AMY and DG in female prairie voles (Lieberwirth et al., 2012).

It is important to note that the social environment not only directly affects cell birth/death in the adult brain but also modulates the effect of other environmental factors on adult neurogenesis. For instance, short-term running increased hippocampal cell proliferation in group-housed male rats (Stranahan et al., 2006) and survival in group-housed male and female rats (Stranahan et al., 2006; Leasure and Decker, 2009), but this effect disappeared in socially isolated rats. Furthermore, the effect of social isolation does not seem to be restricted to separation from other adults. Female rats showed a significant reduction in hippocampal cell proliferation in response to repeated separation from their offspring (6 h per day for 14 consecutive days; Sung et al., 2010).

\section{SOCIAL DEFEAT}

Social defeat (a paradigm in which an animal defends its home cage against an unfamiliar same-sex intruder resulting in the defeat of the intruder) is a powerful psychosocial stressor leading to dramatic changes in physiology (e.g., activation of the hypothalamicpituitary-adrenal axis; Keeney et al., 2006), neuroanatomy (e.g., reduction in dendritic branching and neuronal cell loss; McEwen, 2010), and behavior (e.g., deficits in social interaction and mating behavior as well as an increase in anxiety; reviewed by Martinez et al., 1998). Such an aversive social experience also affects adult neurogenesis. For example, stressful interactions with dominant and aggressive conspecifics significantly alter adult neurogenesis in a variety of mammalian species. In male tree shrews (Tupaia belangeri) and common marmoset monkeys (Callithrix jacchus), the acute $(1 \mathrm{~h})$ social interaction with a dominant same-sex conspecific significantly reduced cell proliferation in the DG of the defeated individuals (Gould et al., 1997, 1998). Contrary to the effect of acute social defeat in marmosets and tree shrews, the acute social defeat exposure (single or three consecutive defeat exposures) did not affect hippocampal cell proliferation in male CFW mice (Yap et al., 2006). In rats, the 20-min exposure to a dominant same-sex conspecific did not affect cell proliferation in the DG, however, it significantly reduced both 1 and 4 -week survival of hippocampal cells in the subordinate rats (Thomas et al., 2007).

Similar to the effect of acute psychosocial stress, sub-chronic social defeat also affected adult neurogenesis. For example, in male Wistar rats, daily social defeat for 5 consecutive days reduced 
the number of adult-generated immature neurons in the DG (van Bokhoven et al., 2011). Fewer BrdU-labeled cells were also observed in the DG, but not in the AMY, following repeated daily (7 consecutive days) social defeat stress in male C57BL mice (Mitra et al., 2006). Further, in male CFW mice, 10 days of daily social defeat significantly reduced hippocampal cell proliferation, and interestingly, an inverse correlation between the number of adultgenerated cells and total number of received bites was observed (Yap et al., 2006). In male Wistar rats, 18 days of daily social defeat reduced not only cell proliferation but also cell survival in the DG (Czeh et al., 2002). Neuronal differentiation (as assessed by BrdU/NeuN double-labeling) was not affected by the social defeat paradigm. Furthermore, long-term psychosocial stress has also been shown to affect adult neurogenesis. In adult male tree shrews, 28 or 35 consecutive days of psychosocial stress (consisting of 1-h daily social defeat and mesh-housed with dominant-male) significantly reduced hippocampal cell proliferation in male tree shrews (Czeh et al., 2001; van der Hart et al., 2002). This reduction in hippocampal cell proliferation due to chronic psychosocial stress was age-dependent, the oldest subgroup showed the greatest vulnerability to stress (Simon et al., 2005). Long-term chronic resident intruder stress (social defeat for 35 consecutive days) also reduced cell proliferation in the prefrontal cortex (PFC), in addition to the DG, and impaired cell survival in the PFC and DG in the adult rats (Czeh et al., 2007). No effect on cell proliferation or survival was observed in the SVZ or primary motor cortex. Finally, social interactions via a dominant-subordinate hierarchy also altered adult neurogenesis. In a study in male Sprague-Dawley rats, chronic exposure (14 days) to a dominance hierarchy affected hippocampal neurogenesis differentially: it had no effect on hippocampal cell proliferation and neuronal differentiation (assessed by BrdU/NeuN and BrdU/TuJ1 double-labeling), but it facilitated hippocampal cell survival in dominate males in comparison to their subordinate counterparts and control males (no experience of dominance hierarchy; Kozorovitskiy and Gould, 2004).

\section{PREDATOR ODOR}

In addition to stressful encounters with conspecifics, interactions with non-conspecifics, especially if the non-conspecific poses a threat (e.g., being a predator), can also potentially lead to psychosocial stress, altering adult neurogenesis. For example, trimethyl thiazoline (TMT), a major component of fox feces, represents a natural predator odor to rodents such as rats and mice (Wallace and Rosen, 2000; Staples, 2010). Although a brief (20min) exposure to TMT did not significantly alter hippocampal cell proliferation (Thomas et al., 2006), 1-h exposure to TMT significantly reduced cell proliferation in the DG of male (Tanapat et al., 2001; Falconer and Galea, 2003), but not female (Falconer and Galea, 2003), rats, in comparison to exposure to saline or neutral non-threatening odors (such as mint or orange). In addition, hippocampal cell survival 1 week after the predator odor exposure was significantly reduced, compared to the saline controls; however, this group difference disappeared 3 weeks later (Tanapat et al., 2001). Neuronal differentiation (assessed by BrdU/TuJ1, BrdU/NeuN, or BrdU/NSE double-labeling) was not affected by 1-h predator odor exposure (Tanapat et al., 2001; Falconer and Galea, 2003). These data indicate that exposure to predator odor may induce stress responses, impairing hippocampal neurogenesis in a sex-specific manner.

\section{HORMONAL REGULATION OF SOCIAL INTERACTIONS ON ADULT NEUROGENESIS}

A variety of hormones, neurotransmitters, and signaling molecules have been implicated in the regulation of adult neurogenesis (for review see Grote and Hannan, 2007; Fowler et al., 2008; Pawluski et al., 2009). Social interactions, as reviewed above, have been shown to modulate the levels of peripherally and centrally released hormones. For example, mating behaviors are associated with alterations in peripherally released gonadal steroid hormones including testosterone and estrogen (Valenstein and Young, 1955; Carter et al., 1989; Ganong, 1997; Fowler et al., 2003; Becker et al., 2005); the gestation and maternal postpartum period are associated with changes in luteinizing hormone, prolactin, and estrogen (Garland et al., 1987; Pawluski et al., 2009); and aversive social interactions (i.e., interactions causing psychosocial stress) are associated with an increased activity of the hypothalamic-pituitary-adrenal axis leading to a greater release of corticotrophin-releasing hormone, adrenocorticotropic hormone, and glucocorticoids (reviewed in Tsigos and Chrousos, 2002; Lightman, 2008). As these peripheral released hormones can easily cross the blood brain barrier and/or can be released in the brain and become centrally acting factors, it is important to note that the DG, a traditional neurogenic brain region, as well as other non-traditional neurogenic brain regions, such as the AMY and MPOA, have been documented to contain hormonal receptors, e.g., adrenal receptors and estrogen receptors (McEwen, 1994; Weiland et al., 1997; Tabori et al., 2005). Therefore, social interactions may induce distinct patterns of hormonal release, and these hormones can act centrally on their receptors to modulate regionspecific adult neurogenesis (e.g., Mazzucco et al., 2006). Here, we will summarize the literature focusing on several hormones with distinguished roles in social interactions to illustrate the hormonal involvement in adult neurogenesis.

Levels of gonadal steroid hormones (such as estrogens and testosterone) change depending on reproductive states as well as during sociosexual interactions. For example, ovarian estrogens in female rats fluctuated across the estrous cycle (Shaikh, 1971; Pawluski et al., 2009) and the level of ovarian estrogens was associated with female's mating behavior (Powers, 1970). It has been reported that hippocampal cell proliferation in female rats was higher during proestrus (high level of estrogen) than during estrus or diestrus (low level of estrogen) in an ovarian cycle, indicating a positive correlation between circulating levels of estrogen and cell proliferation in the female rat hippocampus (Tanapat et al., 1999). Furthermore, ovariectomy reduced, whereas estrogen replacement in ovariectomized female rats increased, hippocampal cell proliferation in a dose- and time-dependent manner, suggesting that estrogen facilitates hippocampal cell proliferation (Tanapat et al., 1999, 2005; Ormerod et al., 2003; Barha et al., 2009). Repeated estrogen administration (pulsatile exposure) in ovariectomized female, but not gonadectomized male, rats also increased hippocampal cell proliferation, but reduced hippocampal cell survival (Barker and Galea, 2008). By using pharmacological activation of estrogen receptors, a study revealed 
that the estrogen-facilitated increase in hippocampal cell proliferation was likely modulated by an estrogen receptor-mediated mechanism (Mazzucco et al., 2006). Additional evidence for the involvement of the estrogen receptor comes from a study showing that pharmacological blocking of estrogen receptor alpha or beta prevented the estrogen-facilitated hippocampal cell proliferation (Nagy et al., 2005). Furthermore, research has evaluated the effect of androgens on hippocampal adult neurogenesis. In particular, castration in male rats significantly decreased hippocampal cell survival, whereas testosterone replacement in castrated male rats prevented this reduction (Spritzer and Galea, 2007). These data suggest that androgens also have effects on hippocampal adult neurogenesis; however, it is not clear if these effects in rats are the result of direct androgenic action or if androgens affect neurogenesis via an aromatase-mediated pathway.

The notion that gonadal steroid hormones, both estrogens and androgens, modulate adult neurogenesis is also supported by data from studies in voles. It should be noted that female voles are induced ovulators and the exposure to a male or its chemosensory cues is necessary to induce behavioral estrus which is associated with a dramatic rise in estrogen (Cohen-Parsons and Carter, 1987). Indeed, $48 \mathrm{~h}$ of cohabitation with a male were sufficient to induce behavioral estrus and resulted in a significant increase in SVZ cell proliferation in female prairie voles compared to females that either cohabited with a sibling or a novel female (Smith et al., 2001). This effect was mediated by estrogen as ovariectomy eliminated, whereas estrogen replacement in ovariectomized females restored, the effect of male exposure on cell proliferation in the SVZ of female prairie voles. Further, reproductively active male meadow voles showed enhanced hippocampal cell survival compared to reproductively inactive males (Ormerod and Galea, 2003). Estrogen treatment also enhanced cell proliferation in the AMY of ovariectomized female meadow voles; in particular, this increase was observed in subnuclei of the AMY with a high density of estrogen receptors, namely the cortical and medial AMY (Fowler et al., 2005). Further, testosterone administration increased hippocampal cell survival in castrated male meadow voles compared to vehicle treatment (Ormerod et al., 2004). In castrated male meadow voles, the treatment with estrogen and testosterone, but not dihydrotestosterone, significantly increased cell proliferation in the cortical and medial nuclei of the AMY (Fowler et al., 2003). It is important to note, that aromatase can aromatize testosterone allowing it to activate estrogen receptors, while DHT is a non-aromatizable androgen. Therefore, these data suggest that an estrogen receptor-mediated mechanism may modulate the effects of gonadal steroid hormones on adult neurogenesis.

In addition to the effects of gonadal steroids, glucocorticoids have inhibitory/suppressive effects on cell proliferation (see reviews by Mirescu and Gould, 2006; Pawluski et al., 2009). For example, cell proliferation varies according to the natural changes in glucocorticoid levels across the lifespan. In particular, hippocampal cell proliferation is high during the early postnatal period (when glucocorticoid levels are low; Gould et al., 1991) and diminishes with age (when glucocorticoid levels become elevated; Cameron and McKay, 1999). The inhibitory effects of glucocorticoids on cell proliferation are further demonstrated by studies showing that glucocorticoid administration during the postnatal period or in adulthood inhibited, while the experimental removal of glucocorticoids (e.g., via adrenalectomy) increased, cell proliferation in adult as well as senescent rats (Gould et al., 1992; Cameron and Gould, 1994; Cameron and McKay, 1999). In addition to the aging-induced increase in glucocorticoids, stressful stimuli also induced an increase in glucocorticoid levels, which in turn suppressed hippocampal cell proliferation and survival (Tanapat et al., 2001). Using both agonists and antagonists, research also showed that glucocorticoids have inhibitory effects on adult neurogenesis via both mineralocorticoid and glucocorticoid receptors (Wong and Herbert, 2005).

Similar to gonadal steroid hormones, hormones such as luteinizing hormone, prolactin, and oxytocin that are involved in the regulation of reproduction (i.e., pregnancy, parturition, and lactation) also seem to affect cell proliferation. Exposure to an unfamiliar male significantly changed the pulsatile release pattern of luteinizing hormone in female sheep and upregulated hippocampal cell proliferation (Hawken et al., 2009). In female mice, exposure to male pheromones or the administration of luteinizing hormone upregulated hippocampal cell proliferation, whereas such an increase in hippocampal cell proliferation was not observed in luteinizing hormone receptor knockout mice (Mak et al., 2007). Further, prolactin levels are increased in pregnant as well as pseudopregnant mice that show an increase in cell proliferation in the SVZ (Shingo et al., 2003). Experimental prolactin administration in female mice or exposure to male pheromones resulted in the upregulation of cell proliferation in the SVZ; whereas such an effect was absent in female mice whose prolactin receptors were knocked out (Mak et al., 2007). In addition, peripheral as well as central oxytocin administration upregulates cell proliferation in the ventral, but not dorsal, hippocampus in male Sprague-Dawley rats (Leuner et al., 2012). Chronic peripheral oxytocin administration also increased cell survival in the ventral hippocampus without affecting neuronal differentiation.

\section{ADULT NEUROGENESIS IN HUMANS}

Similar to other mammalian species, neurogenesis has also been reported in the adult human brain. In an early study, BrdU injections with immunohistochemical detection of BrdU-labeling, a common method used in rodent research, was utilized to study adult neurogenesis in humans (Eriksson et al., 1998). BrdU was injected in terminally ill cancer patients. Adult-generated cells were found in the DG and SVZ and some of these BrdU-labeled cells also co-labeled with a mature neuronal marker such as calbindin, NeuN, and neuron-specific enolase (NSE). Such co-labeling indicates that a proportion of these adult-generated cells expressed a neuronal phenotype. This seminal study firmly demonstrated, for the first time, that continuing neurogenesis exists in the adult human brain. However, it should be noted that as ethical concerns were raised regarding routine BrdU administration in humans (Cooper-Kuhn and Kuhn, 2002), subsequent studies primarily used endogenous cell proliferation markers to examine human adult neurogenesis. These markers include Ki67, PCNA, MCM2, and phosphorylated histone H3 (for review see Sierra et al., 2011). These studies further confirmed the finding that even the healthy human brain exhibits adult neurogenesis. For example, a portion of Dcx-labeled cells in the adult human DG, particularly in 


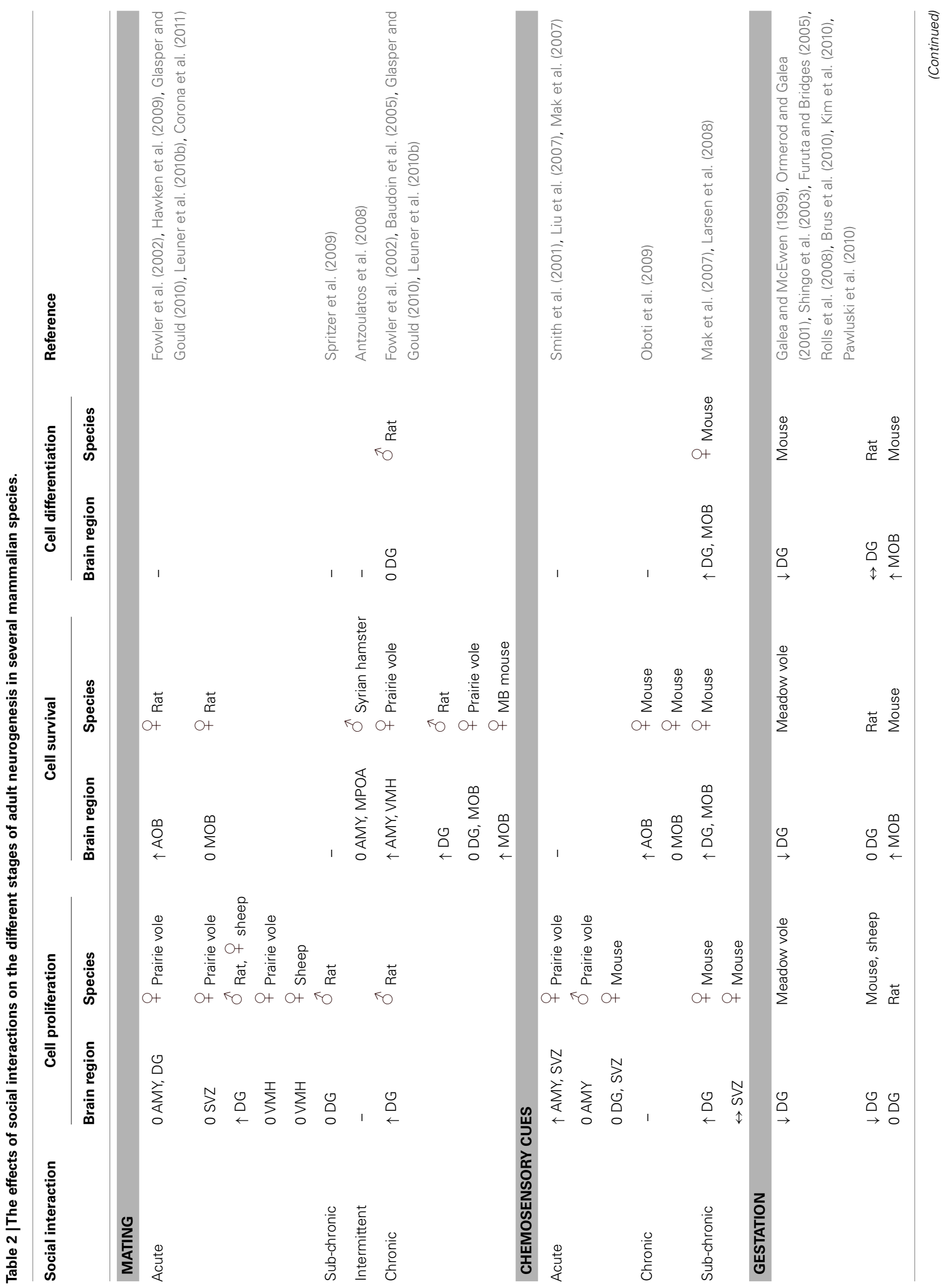




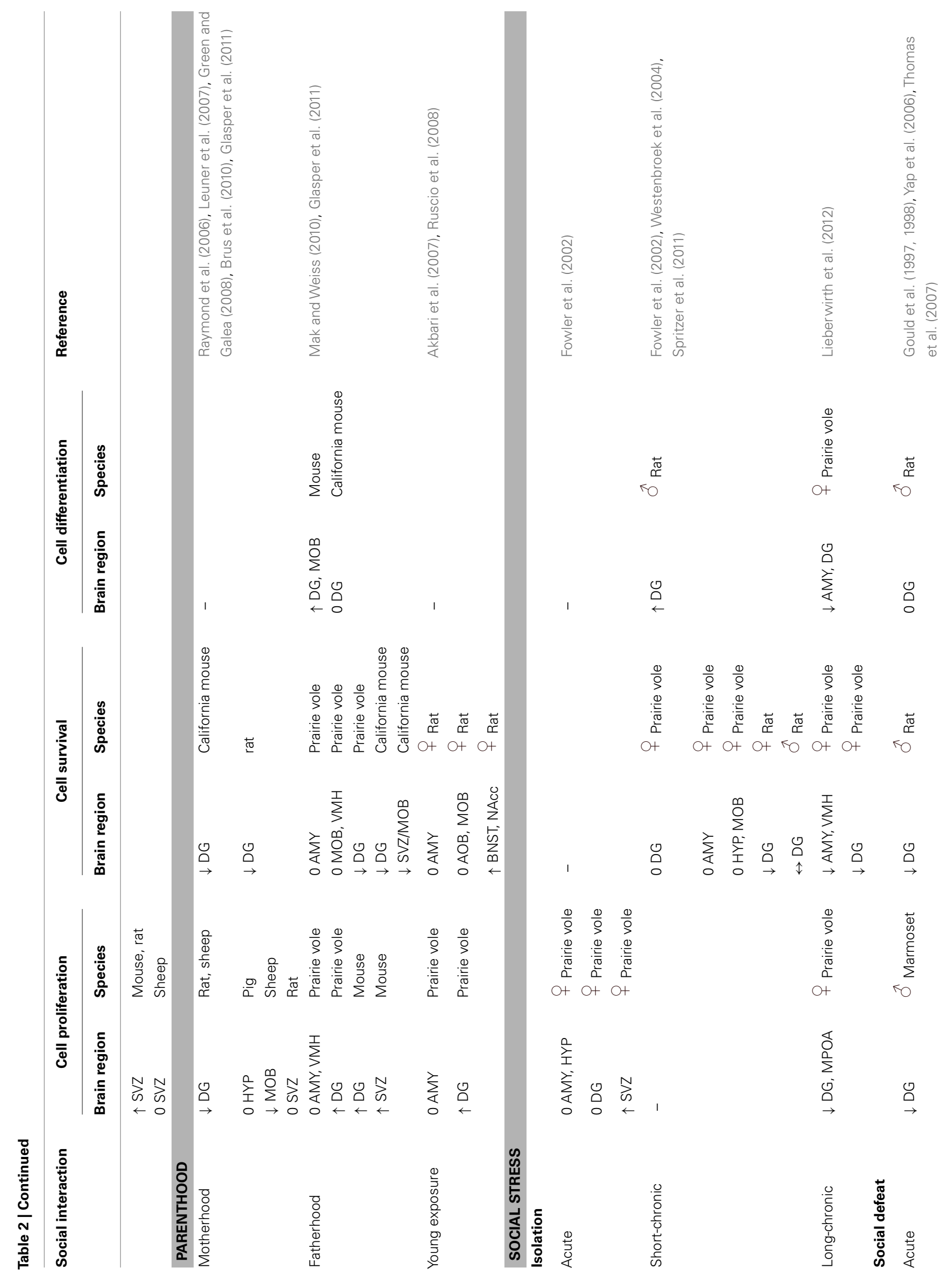



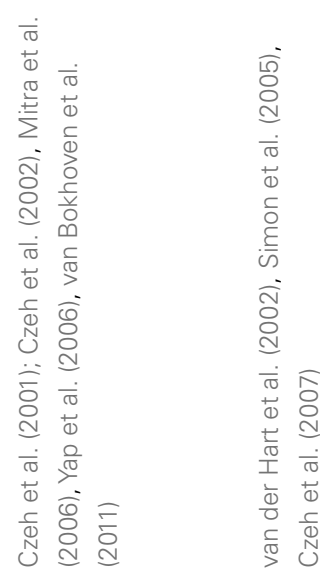

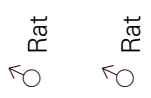

the subgranular zone, also expressed proliferation markers, such as Ki67, PCNA, MCM-2, or a mature neuronal marker, NeuN, suggesting the presence of adult-generated neurons (Knoth et al., 2010). In addition, neuroblast-like cells were found in the human SVZ (Weickert et al., 2000) and rostral migratory stream (Curtis et al., 2007). Interestingly, these neuroblasts exhibited a migratory morphology (Curtis et al., 2007; Kam et al., 2009) and co-expressed Dcx (Wang et al., 2011), providing further evidence for adult neurogenesis in the human brain. Finally, newly generated neurons were also found in the MOB of adult human brains, wherein Ki67-, PCNA-, and PSA-NCAM-labeled cells indicated the occurrence of cell proliferation. Further, Dcx-labeling and TuJ1/calretinin or $\mathrm{TuJ}$ 1/parvalbumin co-labeling indicated that a portion of adultgenerated cells adopted a neuronal phenotype (Bedard and Parent, 2004). Recently, new methods such as ${ }^{14} \mathrm{C}$ retrospective labeling (Spalding et al., 2005), magnetic resonance imaging (MRI; Bulte and Modo, 2011), and cerebral blood volume measurements (CBV; Pereira et al., 2007) have also been applied to study adult neurogenesis in the human brain. However, these techniques are not yet commonly used (reviewed by Sierra et al., 2011).

Estimating the magnitude of hippocampal neurogenesis in the adult human brain suggests that new neurons may play a potential role in human behavior (Snyder and Cameron, 2011). Adultgenerated neurons are vulnerable and sensitive to a variety of endogenous and exogenous factors and it has been suggested that disrupting the maturation and integration of these new neurons may contribute to deficits in cognitive and behavioral functions (Danzer, 2008). As experimentally manipulating the social environment to examine its effects on adult neurogenesis in the human brain is impossible, the majority of studies examining alterations of adult neurogenesis in humans have focused on comparisons between healthy people and those with neurodegenerative diseases (Sierra et al., 2011). Following severe, acute pathological stimuli including stroke, seizure, or trauma, adult neurogenesis was generally increased, further illustrating the potential of the adult human brain to generate new cells (see review by Winner et al., 2011; Zheng et al., 2011). Alterations in human adult neurogenesis have also been reported in patients with various neurodegenerative diseases including Alzheimer's, Huntington's, and Parkinson's disease (see review by Sierra et al., 2011; Winner et al., 2011). The chronic and progressive loss of neurons and glial cells in the brain is a common characteristic of these neurodegenerative diseases, indicating that cell birth and survival in the adult human brain can be modulated by pathological factors. Furthermore, patients with neurodegenerative diseases usually have deficits in cognitive and behavioral functions, suggesting a potential functional role of adult-generated neurons in the human brain. In addition, a recent study showed a significant positive correlation between the regenerative capacity of human hippocampal tissue in vitro and memory (Coras et al., 2010). It needs to be pointed out that although in recent years, adult neurogenesis has become one of the hottest topics in neuroscience research, only a small portion (about $8 \%$ ) of published studies deal with human data (Sierra et al., 2011). Therefore, more efforts are needed to study adult neurogenesis in humans as it may offer a greater potential for the development of neuron replacement therapies for treatments of neurodegenerative 
diseases. In addition, as animal research has suggested the involvement of social interactions to affect adult neurogenesis, such studies should also be considered in examining adult neurogenesis in humans.

\section{CONCLUSION}

Social interactions affect one's psychological, physiological, and behavioral functions. As reviewed above, social interactions also modulate adult neurogenesis and this modulation varies depending on the type of social stimulus (positive versus aversive), brain region, stage of adult neurogenesis (e.g., proliferation, survival, and differentiation), and species. While some conflicting data exist (see Table 2), it seems that acute and chronic sociosexual interactions, as positive stimuli, facilitate cell proliferation and survival across distinct brain regions; whereas aversive social interactions leading to psychosocial stress impair adult neurogenesis. Interestingly, the effect of parenthood may depend on the level of parental investment. In particular, both motherhood and fatherhood in bi-parental species are characterized by high parental investment, which may ultimately cause the suppression in adult neurogenesis. In contrast, in species with low paternal investment (e.g., non-paternal species), fatherhood seems to facilitate adult neurogenesis. Hormonal changes have also been associated with social interactions and these may underlie the differential effects of social stimuli on adult neurogenesis. Unfortunately, there are only a limited amount of studies documenting that social interactions alter adult neurogenesis.

Furthermore, very few studies have examined the functional significance of adult-generated neurons in mediating physiological and behavioral functions that change following social interactions. On the contrary, several studies using various strategies have been used to link adult neurogenesis to learning and memory. One strategy involves the assessment of a correlative relationship between the number of adult-generated neurons in the hippocampus or olfactory system and the effect on hippocampal or olfactory function, respectively. For example, environmental enrichment and exercise lead to enhanced hippocampal adult neurogenesis which is correlated positively with performance on a spatial task (Kempermann et al., 1997; van Praag et al., 2005); whereas a reduction in adult neurogenesis is correlated with learning impairments (Lemaire et al., 2000; Drapeau et al., 2003). Similarly, an increase in the number of olfactory bulb neurons is

\section{REFERENCES}

Achenbach, G. G., and Snowdon, C. T. (2002). Costs of caregiving: weight loss in captive adult male cottontop tamarins (Saguinus oedipus) following the birth of infants. Int. J. Primatol. 23, 179-189.

Adams, K. B., Sanders, S., and Auth, E. A. (2004). Loneliness and depression in independent living retirement communities: risk and resilience factors. Aging Ment. Health 8, 475-485.

Akbari, E. M., Chatterjee, D., Levy, F., and Fleming, A. S. (2007). Experience-dependent cell survival in the maternal rat brain. Behav. Neurosci. 121, 1001-1011.

Alpass, F. M., and Neville, S. (2003). Loneliness, health and depression in older males. Aging Ment. Health 7, 212-216.

Antzoulatos, E., Magorien, J. E., and Wood, R. I. (2008). Cell proliferation and survival in the mating circuit of adult male hamsters: effects of testosterone and sexual behavior. Horm. Behav. 54, 735-740.

Atkinson, H. C., and Waddell, B. J. (1995). The hypothalamicpituitary-adrenal axis in rat pregnancy and lactation: circadian

associated with enhanced odor memory (Rochefort et al., 2002). Future studies should evaluate whether alterations (enhancement or reduction) of adult neurogenesis in response to social interactions modulates subsequent social behaviors. Another strategy to examine the functional significance of adult neurogenesis uses immunodouble-labeling for BrdU (labeling adult-generated cells) with an immediate early gene product, such as cFos or zif268 (labeling activated neurons). The co-label indicates that adultgenerated neurons participate in a functional network. Using this method, activation of adult-generated neurons has been repeatedly shown in the hippocampus in response to spatial learning and memory tasks (Kee et al., 2007; Tashiro et al., 2007). In addition, Huang and Bittman (2002) showed the activation of adult-generated olfactory neurons in male golden hamsters exposed to estrous females. However, future studies are needed to systematically evaluate whether adult-generated cells can be activated in response to a variety of social interactions (such as mating and parental behavior). Lastly, the direct manipulation (i.e., suppression of adult neurogenesis) can be used to examine the functional significance of adult-generated cells. Pharmacologically suppressing adult neurogenesis, using antimitotic agents such as methylazoxymethanol (MAM) or DNA-alkylating agent temozolomide (TMZ), has shown that adult-generated hippocampal neurons may play a role in hippocampal learning and memory (Shors et al., 2001; Bruel-Jungerman et al., 2005; Garthe et al., 2009). Furthermore, suppression of olfactory bulb adult neurogenesis using cytosine arabinoside (AraC) prevents the display of preference for a dominant versus a subordinate male in female mice (Mak et al., 2007). Similarly, focal irradiation and viral-based ablation of adult neurogenesis in the hippocampus caused deficits in spatial tasks (Clelland et al., 2009; Jessberger et al., 2009). However, such techniques have not yet been used to examine the effects of adult neurogenesis ablation on social behaviors. Needless to say, additional studies are required to systematically investigate the potential involvement of adult-generated neurons in response to social interactions and in mediating subsequent physiological and behavioral functions.

\section{ACKNOWLEDGMENTS}

We are grateful to Kelly Lei and Adam S. Smith for their critical reading of the manuscript. This research was supported by NIH grants NIMHR01-089852 and NIDAK02-023048.

variation and interrelationship of plasma adrenocorticotropin and corticosterone. Endocrinology 136, 512-520.

Barha, C. K., Lieblich, S. E., and Galea, L. A. (2009). Different forms of oestrogen rapidly upregulate cell proliferation in the dentate gyrus of adult female rats. J. Neuroendocrinol. 21, 155-166.

Barker, J. M., and Galea, L. A. (2008). Repeated estradiol administration alters different aspects of neurogenesis and cell death in the hippocampus of female, but not male, rats. Neuroscience 152, 888-902.
Baudoin, C., Busquet, N., Dobson, F. S., Gheusi, G., Feron, C., Durand, J. L., Heth, G., Patris, B., and Todrank, J. (2005). Male-female associations and female olfactory neurogenesis with pair bonding in Mus spicilegus. Biol. J. Linn. Soc. Lond. 84, 323-334.

Becker, J. B., Arnold, A. P., Berkley, K. J., Blaustein, J. D., Eckel, L. A., Hampson, E., Herman, J. P., Marts, S., Sadee, W., Steiner, M., Taylor, J., and Young, E. (2005). Strategies and methods for research on sex differences in brain and behavior. Endocrinology 146, 1650-1673. 
Bedard, A., and Parent, A. (2004). Evidence of newly generated neurons in the human olfactory bulb. Brain Res. Dev. Brain Res. 151, 159-168.

Bell, N. J., Forthun, L. F., and Sun, S. W. (2000). Attachment, adolescent competencies, and substance use: developmental considerations in the study of risk behaviors. Subst. Use Misuse 35, 1177-1206.

Bernier, P. J., Bedard, A., Vinet, J., Levesque, M., and Parent, A. (2002). Newly generated neurons in the amygdala and adjoining cortex of adult primates. Proc. Natl. Acad. Sci. U.S.A. 99, 11464-11469.

Brennan, P. A., and Keverne, E. B. (2004). Something in the air? New insights into mammalian pheromones. Curr. Biol. 14, R81R89.

Brennan, P. A. (2010). "Pheromones and mammalian behavior," in The Neurobiology of Olfaction, ed. A. Menini (Boca Raton, FL: CRC Press), 157-180.

Bridges, R. S., and Bridges, R. S. (2008). Neurobiology of the Parental Brain. London: Academic Press.

Bronson, F. H. (1989). Mammalian Reproductive Biology. Chicago: University of Chicago Press.

Bruel-Jungerman, E., Laroche, S., and Rampon, C. (2005). New neurons in the dentate gyrus are involved in the expression of enhanced longterm memory following environmental enrichment. Eur. J. Neurosci. 21, 513-521.

Brus, M., Meurisse, M., Franceschini, I., Keller, M., and Levy, F. (2010). Evidence for cell proliferation in the sheep brain and its downregulation by parturition and interactions with the young. Horm. Behav. 58, 737-746.

Bulte, J. W. M., and Modo, M. M. J. J. (2011). Magnetic Resonance Neuroimaging: Methods and Protocols. New York, NY: Humana Press.

Caba, M., Silver, R., Gonzalez-Mariscal, G., Jimenez, A., and Beyer, C. (1996). Oxytocin and vasopressin immunoreactivity in rabbit hypothalamus during estrus, late pregnancy, and postpartum. Brain Res. 720, 7-16.

Cameron, H. A., and Gould, E. (1994). Adult neurogenesis is regulated by adrenal steroids in the dentate gyrus. Neuroscience 61, 203-209.

Cameron, H. A., and McKay, R. D. (1999). Restoring production of hippocampal neurons in old age. Nat. Neurosci. 2, 894-897.

Cameron, H. A., and Mckay, R. D. (2001). Adult neurogenesis produces a large pool of new granule cells in the dentate gyrus. J. Comp. Neurol. 435, 406-417.

Campbell, J. C., Laugero, K. D., Van Westerhuyzen, J. A., Hostetler, C. M., Cohen, J. D., and Bales, K. L. (2009). Costs of pair-bonding and paternal care in male prairie voles (Microtus ochrogaster). Physiol. Behav. 98, 367-373.

Carter, C. S., Witt, D. M., Manock, S. R., Adams, K. A., Bahr, J. M., and Carlstead, K. (1989). Hormonal correlates of sexual behavior and ovulation in male-induced and postpartum estrus in female prairie voles. Physiol. Behav. 46, 941-948.

Cherng, C. G., Lin, P. S., Chuang, J. Y., Chang, W. T., Lee, Y. S., Kao, G. S., Lai, Y. T., and Yu, L. (2011). Presence of conspecifics and their odorimpregnated objects reverse stressdecreased neurogenesis in mouse dentate gyrus. J. Neurochem. 112, 1138-1146.

Christie, B. R., and Cameron, H. A. (2006). Neurogenesis in the adult hippocampus. Hippocampus 16, 199-207.

Clelland, C. D., Choi, M., Romberg, C., Clemenson, G. D. Jr., Fragniere, A., Tyers, P., Jessberger, S., Saksida, L. M., Barker, R. A., Gage, F. H., and Bussey, T. J. (2009). A functional role for adult hippocampal neurogenesis in spatial pattern separation. Science 325, 210-213.

Cohen-Parsons, M., and Carter, C. S. (1987). Males increase serum estrogen and estrogen receptor binding in brain of female voles. Physiol. Behav. 39, 309-314.

Cooper-Kuhn, C. M., and Kuhn, H. G. (2002). Is it all DNA repair? Methodological considerations for detecting neurogenesis in the adult brain. Brain Res. Dev. Brain Res. 134, 13-21.

Coras, R., Siebzehnrubl, F. A., Pauli, E., Huttner, H. B., Njunting, M., Kobow, K., Villmann, C., Hahnen, E., Neuhuber, W., Weigel, D., Buchfelder, M., Stefan, H., Beck, H., Steindler, D. A., and Blumcke, I. (2010). Low proliferation and differentiation capacities of adult hippocampal stem cells correlate with memory dysfunction in humans. Brain 133, 3359-3372.

Corona, R., Larriva-Sahd, J., and Paredes, R. G. (2011). Paced-mating increases the number of adult new born cells in the internal cellular (granular) layer of the accessory olfactory bulb. PLOS ONE 6, e19380. doi:10.1371/journal.pone.0019380

Cowley, J. J., and Brooksbank, B. W. (1991). Human exposure to putative pheromones and changes in aspects of social behaviour. $J$.
Steroid Biochem. Mol. Biol. 39, 647-659.

Curtis, M. A., Kam, M., Nannmark, U., Anderson, M. F., Axell, M. Z. Wikkelso, C., Holtas, S., Van RoonMom, W. M., Bjork-Eriksson, T., Nordborg, C., Frisen, J., Dragunow, M., Faull, R. L., and Eriksson, P. S. (2007). Human neuroblasts migrate to the olfactory bulb via a lateral ventricular extension. Science 315, 1243-1249.

Curtis, R. (1995). Stress, personality and illness: the move from generality to specificity in current research trends. Ir. J. Psychol. 16, 299-321.

Czeh, B., Michaelis, T., Watanabe, T., Frahm, J., De Biurrun, G., Van Kampen, M., Bartolomucci, A., and Fuchs, E. (2001). Stress-induced changes in cerebral metabolites, hippocampal volume, and cell proliferation are prevented by antidepressant treatment with tianeptine. Proc. Natl. Acad. Sci. U.S.A. 98 12796-12801.

Czeh, B., Muller-Keuker, J. I., Rygula, R., Abumaria, N., Hiemke, C., Domenici, E., and Fuchs, E. (2007). Chronic social stress inhibits cell proliferation in the adult medial prefrontal cortex: hemispheric asymmetry and reversal by fluoxetine treatment. Neuropsychopharmacology 32, 1490-1503.

Czeh, B., Welt, T., Fischer, A. K., Erhardt, A., Schmitt, W., Muller, M. B., Toschi, N., Fuchs, E., and Keck, M. E. (2002). Chronic psychosocial stress and concomitant repetitive transcranial magnetic stimulation: effects on stress hormone levels and adult hippocampal neurogenesis. Biol. Psychiatry 52, 1057-1065.

Danzer, S. C. (2008). Postnatal and adult neurogenesis in the development of human disease. Neuroscientist. 14, 446-458.

Dayer, A. G., Cleaver, K. M., Abouantoun, T., and Cameron, H. A. (2005). New GABAergic interneurons in the adult neocortex and striatum are generated from different precursors. J. Cell Biol. 168, 415-427.

Dewsbury, D. A. (1975). Diversity and adaptation in rodent copulatory behavior. Science 190, 947-954.

Drapeau, E., Mayo, W., Aurousseau, C., Le Moal, M., Piazza, P. V., and Abrous, D. N. (2003). Spatial memory performances of aged rats in the water maze predict levels of hippocampal neurogenesis. Proc. Natl. Acad. Sci. U.S.A. 100, 14385-14390.

Dulac, C., and Torello, A. T. (2003). Molecular detection of pheromone signals in mammals: from genes to behaviour. Nat. Rev. Neurosci. 4, 551-562.

Ellickson, P. L., Collins, R. L., and Bell, R. M. (1999). Adolescent use of illicit drugs other than marijuana: how important is social bonding and for which ethnic groups? Subst. Use Misuse 34, 317-346.

Eng, L. F., Ghirnikar, R. S., and Lee, Y. L. (2000). Glial fibrillary acidic protein: GFAP-thirty-one years (19692000). Neurochem. Res. 25, 1439 1451.

Eriksson, P. S., Perfilieva, E., BjorkEriksson, T., Alborn, A. M., Nordborg, C., Peterson, D. A., and Gage, F. H. (1998). Neurogenesis in the adult human hippocampus. Nat. Med. 4, 1313-1317.

Erskine, M. S., and Kornberg, E. (1992). Acute luteinizing hormone and prolactin responses to paced mating stimulation in the estrous female rat. J. Neuroendocrinol. 4, 173-179.

Falconer, E. M., and Galea, L. A. (2003). Sex differences in cell proliferation cell death and defensive behavior following acute predator odor stress in adult rats. Brain Res. 975, 22-36.

Fietz, J., and Dausmann, K. H. (2003). Costs and potential benefits of parental care in the nocturnal fattailed dwarf lemur (Cheirogaleus medius). Folia Primatol. 74, 246-258.

Flanagan-Cato, L. M., Calizo, L. H., Griffin, G. D., Lee, B. J., and Whisner, S. Y. (2006). Sexual behaviour induces the expression of activityregulated cytoskeletal protein and modifies neuronal morphology in the female rat ventromedial hypothalamus. J. Neuroendocrinol. 18, 857-864.

Fowler, C. D., Freeman, M. E., and Wang, Z. (2003). Newly proliferated cells in the adult male amygdala are affected by gonadal steroid hormones. J. Neurobiol. 57, 257-269.

Fowler, C. D., Johnson, F., and Wang, Z. (2005). Estrogen regulation of cell proliferation and distribution of estrogen receptor-alpha in the brains of adult female prairie and meadow voles. J. Comp. Neurol. 489, 166-179.

Fowler, C. D., Liu, Y., Ouimet, C., and Wang,Z. (2002). The effects of social environment on adult neurogenesis in the female prairie vole. J. Neurobiol. 51, 115-128.

Fowler, C. D., Liu, Y., and Wang, Z. (2008). Estrogen and adult neurogenesis in the amygdala and hypothalamus. Brain Res. Rev. 57, 342-351.

Francis, F., Koulakoff, A., Boucher, D., Chafey, P., Schaar, B., Vinet, M. C., Friocourt, G., Mcdonnell, N., Reiner, O., Kahn, A., Mcconnell, 
S. K., Berwald-Netter, Y., Denoulet, P., and Chelly, J. (1999). Doublecortin is a developmentally regulated, microtubule-associated protein expressed in migrating and differentiating neurons. Neuron 23, 247-256.

Furuta, M., and Bridges, R. S. (2005). Gestation-induced cell proliferation in the rat brain. Brain Res. Dev. Brain Res. 156, 61-66.

Galand, P., and Degraef, C. (1989). Cyclin/PCNA immunostaining as an alternative to tritiated thymidine pulse labelling for marking $S$ phase cells in paraffin sections from animal and human tissues. Cell Tissue Kinet. 22, 383-392.

Galea, L. A., and McEwen, B. S. (1999). Sex and seasonal differences in the rate of cell proliferation in the dentate gyrus of adult wild meadow voles. Neuroscience 89, 955-964.

Ganem, G., Ginane, C., Ostrowski, M. F., and Orth, A. (2005). Assessment of mate preference in the house mouse with reference to investigations on assortative mating. Biol. J. Linn. Soc. Lond. 84, 461-471.

Ganong, W. F. (1997). Review of Medical Physiology. Stamford, CT: Appleton \& Lange.

Garland, H. O., Atherton, J. C., Baylis, C., Morgan, M. R., and Milne, C. M. (1987). Hormone profiles for progesterone, oestradiol, prolactin, plasma renin activity, aldosterone and corticosterone during pregnancy and pseudopregnancy in two strains of rat: correlation with renal studies. J. Endocrinol. 113, 435-444.

Garthe, A., Behr, J., and Kempermann, G. (2009). Adult-generated hippocampal neurons allow the flexible use of spatially precise learning strategies. PLoS ONE 4, e5464. doi:10.1371/journal.pone.0005464

Getz, L. L., and McGuire, B. (1993). A comparison of living singly and in male-female pairs in the prairie vole, Microtus ochrogaster. Ethology 94, 265-278.

Gheusi, G., Ortega-Perez, I., Murray, K., and Lledo, P. M. (2009). A niche for adult neurogenesis in social behavior. Behav. Brain Res. 200, 315-322.

Glasper, E. R., and Gould, E. (2010). Sexual experience enhances adult neurogenesis in the dentate gyrus and affects cognitive and anxietylike behavior in the aging rat. Soc. Neurosci. Abstr. 40, 205.1 (LLL18).

Glasper, E. R., Kozorovitskiy, Y., Pavlic, A., and Gould, E. (2011). Paternal experience suppresses adult neurogenesis without altering hippocampal function in Peromyscus californicus. J. Comp. Neurol. 519, 2271-2281.
Gould, E. (2007). How widespread is adult neurogenesis in mammals? Nat. Rev. Neurosci. 8, 481-488.

Gould, E., Cameron, H. A., Daniels, D. C., Woolley, C. S., and Mcewen, B. S. (1992). Adrenal hormones suppress cell division in the adult rat dentate gyrus. J. Neurosci. 12, 3642-3650.

Gould, E., Mcewen, B. S., Tanapat, P., Galea, L. A., and Fuchs, E. (1997). Neurogenesis in the dentate gyrus of the adult tree shrew is regulated by psychosocial stress and NMDA receptor activation. J. Neurosci. 17, 2492-2498.

Gould, E., Tanapat, P., Mcewen, B. S., Flugge, G., and Fuchs, E. (1998). Proliferation of granule cell precursors in the dentate gyrus of adult monkeys is diminished by stress. Proc. Natl. Acad. Sci. U.S.A. 95, 3168-3171.

Gould, E., Woolley, C. S., Cameron, H. A., Daniels, D. C., and Mcewen, B. S. (1991). Adrenal steroids regulate postnatal development of the rat dentate gyrus: II. Effects of glucocorticoids and mineralocorticoids on cell birth. J. Comp. Neurol. 313, 486-493.

Grattan, D. R. (2001). The actions of prolactin in the brain during pregnancy and lactation. Prog. Brain Res. 133, 153-171.

Grattan, D. R., and Averill, R. L. (1990). Effect of ovarian steroids on a nocturnal surge of prolactin secretion that precedes parturition in the rat. Endocrinology 126, 1199-1205.

Grattan, D. R., Steyn, F. J., Kokay, I. C., Anderson, G. M., and Bunn, S. J. (2008). Pregnancy-induced adaptation in the neuroendocrine control of prolactin secretion. J. Neuroendocrinol. 20, 497-507.

Graziano, F., Bonino, S., and Cattelino, E. (2009). Links between maternal and paternal support, depressive feelings and social and academic self-efficacy in adolescence. Eur. J. Dev. Psychol. 6, 241-257.

Green, A. D., and Galea, L. A. (2008). Adult hippocampal cell proliferation is suppressed with estrogen withdrawal after a hormonesimulated pregnancy. Horm. Behav. 54, 203-211.

Gross, C. G. (2000). Neurogenesis in the adult brain: death of a dogma. Nat. Rev. Neurosci. 1, 67-73.

Grote, H. E., and Hannan, A. J. (2007). Regulators of adult neurogenesis in the healthy and diseased brain. Clin. Exp. Pharmacol. Physiol. 34, 533-545.

Gurley, L. R., Walters, R. A., and Tobey, R. A. (1974). Cell cycle-specific changes in histone phosphorylation associated with cell proliferation and chromosome condensation. J. Cell Biol. 60, 356-364.

Hawken, P. A., Jorre, T. J., Rodger, J. Esmaili, T., Blache, D., and Martin, G. B. (2009). Rapid induction of cell proliferation in the adult female ungulate brain (Ovis aries) associated with activation of the reproductive axis by exposure to unfamiliar males. Biol. Reprod. 80, 1146-1151.

Hersen, M. (2006). Clinician's Handbook of Adult Behavioral Assessment. Boston: Elsevier Academic Press.

House, J. S., Landis, K. R., and Umberson, D. (1988). Social relationships and health. Science 241, 540-545.

Huang, L., and Bittman, E. L. (2002). Olfactory bulb cells generated in adult male golden hamsters are specifically activated by exposure to estrous females. Horm. Behav. 41, 343-350.

Huang, L., Devries, G. J., and Bittman, E. L. (1998). Photoperiod regulates neuronal bromodeoxyuridine labeling in the brain of a seasonally breeding mammal. J. Neurobiol. 36, 410-420.

Huber, G., and Matus, A. (1984). Differences in the cellular distributions of two microtubule-associated proteins, MAP1 and MAP2, in rat brain. J. Neurosci. 4, 151-160.

Hull, E. M., and Rodriguez-Manzo, G. (2009). "Male sexual behavior," in Hormones, Brain and Behavior, 2nd Edn, eds D. W. Pfaff, A. P. Arnold, A. M. Etgen, S. E. Fahrbach, and R. T. Rubin (San Diego: Academic Press), 5-65.

Jankord, R., and Herman, J. P. (2008). Limbic regulation of hypothalamopituitary-adrenocortical function during acute and chronic stress. Ann. N. Y. Acad. Sci. 1148, 64-73.

Jessberger, S., Clark, R. E., Broadbent, N. J., Clemenson, G. D. Jr., Consiglio, A., Lie, D. C., Squire, L. R., and Gage, F. H. (2009). Dentate gyrus-specific knockdown of adult neurogenesis impairs spatial and object recognition memory in adult rats. Learn. Mem. 16, 147-154.

Kam, M., Curtis, M. A., Mcglashan, S. R., Connor, B., Nannmark, U., and Faull, R. L. (2009). The cellular composition and morphological organization of the rostral migratory stream in the adult human brain. J. Chem. Neuroanat. 37, 196-205.

Kavaliers, M., Choleris, E., and Pfaff, D. W. (2005). Recognition and avoidance of the odors of parasitized conspecifics and predators: differential genomic correlates. Neurosci. Biobehav. Rev. 29, 1347-1359.
Kee, N., Sivalingam, S., Boonstra, R., and Wojtowicz, J. M. (2002). The utility of Ki-67 and BrdU as proliferative markers of adult neurogenesis. J. Neurosci. Methods 115, 97-105.

Kee, N., Teixeira, C. M., Wang, A. H., and Frankland, P. W. (2007). Imaging activation of adult-generated granule cells in spatial memory. Nat. Protoc. 2, 3033-3044.

Keeney, A., Jessop, D. S., Harbuz, M. S., Marsden, C. A., Hogg, S., and Blackburn-Munro, R. E. (2006). Differential effects of acute and chronic social defeat stress on hypothalamic-pituitary-adrenal axis function and hippocampal serotonin release in mice. J. Neuroendocrinol. 18, 330-338.

Kempermann, G., Kuhn, H. G., and Gage, F. H. (1997). More hippocampal neurons in adult mice living in an enriched environment. Nature 386, 493-495.

Kiecolt-Glaser, J. K., and Newton, T. L. (2001). Marriage and health: his and hers. Psychol. Bull. 127, 472-503.

Kim, S. K., Hwang, I. K., Yoo, K. Y., Yoo, D. Y., Bae, E., Lee, C. H., Choi, J. H., Choi, J. W., Seong, J. K., Yoon, Y. S., and Won, M. H. (2010). Pregnancy inhibits cell proliferation and neuroblast differentiation without neuronal damage in the hippocampal dentate gyrus in $\mathrm{C} 57 \mathrm{BL} / 6 \mathrm{~N}$ mice. Brain Res. 1315, 25-32.

Kinsley, C. H., Trainer, R., StafissoSandoz, G., Quadros, P., Marcus, L. K., Hearon, C., Meyer, E. A., Hester, N., Morgan, M., Kozub, F. J., and Lambert, K. G. (2006). Motherhood and the hormones of pregnancy modify concentrations of hippocampal neuronal dendritic spines. Horm. Behav. 49, 131-142.

Knoth, R., Singec, I., Ditter, M., Pantazis, G., Capetian, P., Meyer, R. P., Horvat, V., Volk, B., and Kempermann, G. (2010). Murine features of neurogenesis in the human hippocampus across the lifespan from 0 to 100 years. PLoS ONE 5, e8809. doi:10.1371/journal.pone.0008809

Kokoeva, M. V., Yin, H., and Flier, J. S. (2005). Neurogenesis in the hypothalamus of adult mice: potential role in energy balance. Science 310 , 679-683.

Kollack-Walker, S., and Newman, S. W. (1997). Mating-induced expression of c-fos in the male Syrian hamster brain: role of experience, pheromones, and ejaculations. $J$. Neurobiol. 32, 481-501.

Kozorovitskiy, Y., and Gould, E. (2004). Dominance hierarchy influences adult neurogenesis in the dentate gyrus. J. Neurosci. 24, 6755-6759. 
Larsen, C. M., Kokay, I. C., and Grattan, D. R. (2008). Male pheromones initiate prolactin-induced neurogenesis and advance maternal behavior in female mice. Horm. Behav. 53, 509-517.

Leasure, J. L., and Decker, L. (2009). Social isolation prevents exerciseinduced proliferation of hippocampal progenitor cells in female rats. Hippocampus 19, 907-912.

Lee, R. M., and Robbins, S. B. (1998). The relationship between social connectedness and anxiety, self-esteem, and social identity. J. Couns. Psychol. 45, 338-345.

Lemaire, V., Koehl, M., Le Moal, M., and Abrous, D. N. (2000). Prenatal stress produces learning deficits associated with an inhibition of neurogenesis in the hippocampus. Proc. Natl. Acad. Sci. U.S.A. 97, 11032-11037.

Leuner, B., Caponiti, J. M., and Gould, E. (2012). Oxytocin stimulates adult neurogenesis even under conditions of stress and elevated glucocorticoids. Hippocampus 22, 861-868.

Leuner, B., Glasper, E. R., and Gould, E. (2010a). Parenting and plasticity. Trends Neurosci. 33, 465-473.

Leuner, B., Glasper, E. R., and Gould, E. (2010b). Sexual experience promotes adult neurogenesis in the hippocampus despite an initial elevation in stress hormones. PLoS ONE 5, el1597. doi:10.1371/journal.pone.0011597

Leuner, B., Mirescu, C., Noiman, L., and Gould, E. (2007). Maternal experience inhibits the production of immature neurons in the hippocampus during the postpartum period through elevations in adrenal steroids. Hippocampus 17, 434-442.

Levy, F., Gheusi, G., and Keller, M. (2011). Plasticity of the parental brain: a case for neurogenesis. J. Neuroendocrinol. 23, 984-993.

Lieberwirth, C., Liu, Y., Jia, X., and Wang, Z. (2012). Social isolation impairs adult neurogenesis in the limbic system and alters behaviors in female prairie voles. Horm. Behav. doi:10.1016/j.yhbeh.2012.03.005

Lightman, S. L. (2008). The neuroendocrinology of stress: a never ending story. J. Neuroendocrinol. 20, 880-884.

Lillard, L. A., and Waite, L. J. (1995). Til death do us part - marital disruption and mortality. Am. J. Sociol. 100, 1131-1156.

Lin, D. Y., Zhang, S. Z., Block, E., and Katz, L. C. (2005). Encoding social signals in the mouse main olfactory bulb. Nature 434, 470-477.
Lin, S. H., Kiyohara, T., and Sun, B. (2003). Maternal behavior: activation of the central oxytocin receptor system in parturient rats? Neuroreport 14, 1439-1444.

Liu, Y., Curtis, J. T., Fowler, C. D., Meredith, M., and Wang, Z. X. (2007). Chemosensory cues affect adult neurogenesis in the amygdala of prairie voles in a sex-specific manner. Soc. Behav. Neuroendocrinol Abstr. 11, P1.26.

Lledo, P. M., and Saghatelyan, A. (2005). Integrating new neurons into the adult olfactory bulb: joining the network, life-death decisions, and the effects of sensory experience. Trends Neurosci. 28, 248-254.

Lonstein, J. S., and De Vries, G. J. (1999). Comparison of the parental behavior of pair-bonded female and male prairie voles (Microtus ochrogaster). Physiol. Behav. 66, 33-40.

Lonstein, J. S., and De Vries, G. J. (2000). Sex differences in the parental behavior of rodents. Neurosci. Biobehav. Rev. 24, 669-686.

Lucassen, P. J., Meerlo, P., Naylor, A. S., Van Dam, A. M., Dayer, A. G., Fuchs, E., Oomen, C. A., and Czeh, B. (2010). Regulation of adult neurogenesis by stress, sleep disruption, exercise and inflammation: implications for depression and antidepressant action. Eur. Neuropsychopharmacol. 20, 1-17.

Luzzati, F., De Marchis, S., Fasolo, A., and Peretto, P. (2006). Neurogenesis in the caudate nucleus of the adult rabbit. J. Neurosci. 26, 609-621.

Maestripieri, D. (2001). Is there motherinfant bonding in primates? Dev. Rev. 21, 93-120.

Mak, G. K., Enwere, E. K., Gregg, C., Pakarainen, T., Poutanen, M., Huhtaniemi, I., and Weiss, S. (2007). Male pheromone-stimulated neurogenesis in the adult female brain: possible role in mating behavior. Nat. Neurosci. 10, 1003-1011.

Mak, G. K., and Weiss, S. (2010). Paternal recognition of adult offspring mediated by newly generated CNS neurons. Nat. Neurosci. 13, 753-758.

Martinez, I., and Paredes, R. G. (2001). Only self-paced mating is rewarding in rats of both sexes. Horm. Behav. 40, 510-517.

Martinez, M., Calvo-Torrent, A., and Pico-Alfonso, M. A. (1998). Social defeat and subordination as models of social stress in laboratory rodents: a review. Aggress. Behav. 24, 241-256.

Mas, M. (1995). Neurobiological correlates of masculine sexual behavior. Neurosci. Biobehav. Rev. 19, 261-277.

Mazzucco, C. A., Lieblich, S. E., Bingham, B. I., Williamson, M. A., Viau,
V., and Galea, L. A. (2006). Both estrogen receptor alpha and estrogen receptor beta agonists enhance cell proliferation in the dentate gyrus of adult female rats. Neuroscience 141 , 1793-1800.

McEwen, B. S. (1994). Corticosteroids and hippocampal plasticity. Ann. N. Y. Acad. Sci. 746, 134-142.

McEwen, B. S. (2010). Stress, sex, and neural adaptation to a changing environment: mechanisms of neuronal remodeling. Ann. N. Y. Acad. Sci. 1204(Suppl.), E38-E59.

Meisel, R. L., and Mullins, A. J. (2006). Sexual experience in female rodents: cellular mechanisms and functional consequences. Brain Res. 1126, 56-65.

Memberg, S. P., and Hall, A. K. (1995). Dividing neuron precursors express neuron-specific tubulin. J. Neurobiol. 27, 26-43.

Migaud, M., Batailler, M., Segura, S., Duittoz, A., Franceschini, I., and Pillon, D. (2010). Emerging new sites for adult neurogenesis in the mammalian brain: a comparative study between the hypothalamus and the classical neurogenic zones. Eur. J. Neurosci. 32, 2042-2052.

Ming, G. L., and Song, H. (2005). Adult neurogenesis in the mammalian central nervous system. Annu. Rev. Neurosci. 28, 223-250.

Minturn, J. E., Geschwind, D. H., Fryer H. J., and Hockfield, S. (1995). Early postmitotic neurons transiently express TOAD-64, a neural specific protein. J. Comp. Neurol. 355, 369-379.

Mirescu, C., and Gould, E. (2006). Stress and adult neurogenesis. Hippocampus 16, 233-238.

Mitra, R., Sundlass, K., Parker, K. J., Schatzberg, A. F., and Lyons, D. M. (2006). Social stress-related behavior affects hippocampal cell proliferation in mice. Physiol. Behav. 89 123-127.

Mogi, K., Nagasawa, M., and Kikusui, T. (2011). Developmental consequences and biological significance of mother-infant bonding. Prog. Neuropsychopharmacol. Biol. Psychiatry 35, 1232-1241.

Mullen, R. J., Buck, C. R., and Smith, A. M. (1992). NeuN, a neuronal specific nuclear protein in vertebrates. Development 116, 201-211.

Nagy, A. I., Ormerod, B. K., Mazzucco, C., and Galea, L. A. M. (2005). Estradiol-induced enhancement in cell proliferation is mediated through estrogen receptors in the dentate gyrus of adult female rats. Drug Dev. Res. 66, 142-149.
Nowak, R., Porter, R. H., Levy, F., Orgeur, P., and Schaal, B. (2000). Role of mother-young interactions in the survival of offspring in domestic mammals. Rev. Reprod. 5, 153-163.

Numan, M., and Insel, T. R. (2003). The Neurobiology of Parental Behavior. New York: Springer-Verlag.

Nyuyki, K. D., Waldherr, M., Baeuml, S., and Neumann, I. D. (2011). Yes, I am ready now: differential effects of paced versus unpaced mating on anxiety and central oxytocin release in female rats. PLoS ONE 6, e23599. doi:10.1371/journal.pone.0023599

Oatridge, A., Holdcroft, A., Saeed, N., Hajnal, J. V., Puri, B. K., Fusi, L., and Bydder, G. M. (2002). Change in brain size during and after pregnancy: study in healthy women and women with preeclampsia. AJNR Am. J. Neuroradiol. 23, 19-26.

Oboti, L., Savalli, G., Giachino, C., De Marchis, S., Panzica, G. C., Fasolo, A., and Peretto, P. (2009). Integration and sensory experience-dependent survival of newly-generated neurons in the accessory olfactory bulb of female mice. Eur. J. Neurosci. 29, 679-692.

Okano, H. J., and Darnell, R. B. (1997). A hierarchy of $\mathrm{Hu}$ RNA binding proteins in developing and adult neurons. J. Neurosci. 17, 3024-3037.

Okuda, H., Tatsumi, K., Makinodan, M., Yamauchi, T., Kishimoto, T., and Wanaka, A. (2009). Environmental enrichment stimulates progenitor cell proliferation in the amygdala. $J$. Neurosci. Res. 87, 3546-3553.

Ormerod, B. K., and Galea, L. A. (2001). Reproductive status influences cell proliferation and cell survival in the dentate gyrus of adult female meadow voles: a possible regulatory role for estradiol. Neuroscience 102, 369-379.

Ormerod, B. K., and Galea, L. A. (2003). Reproductive status influences the survival of new cells in the dentate gyrus of adult male meadow voles. Neurosci. Lett. 346, 25-28.

Ormerod, B. K., Lee, T. T., and Galea, L. A. (2003). Estradiol initially enhances but subsequently suppresses (via adrenal steroids) granule cell proliferation in the dentate gyrus of adult female rats. J. Neurobiol. 55, 247-260.

Ormerod, B. K., Lee, T. T., and Galea, L. A. (2004). Estradiol enhances neurogenesis in the dentate gyri of adult male meadow voles by increasing the survival of young granule neurons. Neuroscience 128, 645-654.

Pawluski, J. L., Barakauskas, V. E., and Galea, L. A. (2010). Pregnancy decreases oestrogen receptor alpha 
expression and pyknosis, but not cell proliferation or survival, in the hippocampus. J. Neuroendocrinol. 22, 248-257.

Pawluski, J. L., Brummelte, S., Barha, C. K., Crozier, T. M., and Galea, L. A. (2009). Effects of steroid hormones on neurogenesis in the hippocampus of the adult female rodent during the estrous cycle, pregnancy, lactation and aging. Front. Neuroendocrinol. 30, 343-357.

Pereira, A. C., Huddleston, D. E., Brickman, A. M., Sosunov, A. A., Hen, R., Mckhann, G. M., Sloan, R., Gage, F. H., Brown, T. R., and Small, S. A. (2007). An in vivo correlate of exercise-induced neurogenesis in the adult dentate gyrus. Proc. Natl. Acad. Sci. U.S.A. 104, 5638-5643.

Pfaus, J. G., and Heeb, M. M. (1997). Implications of immediateearly gene induction in the brain following sexual stimulation of female and male rodents. Brain Res. Bull.44, 397-407.

Powers, J. B. (1970). Hormonal control of sexual receptivity during the estrous cycle of the rat. Physiol. Behav. 5, 831-835.

Properi, E. (1997). Mutliple roles of the proliferating cell nuclear antigen: DNA replication, repair and cell cycle control. Prog. Cell Cycle Res. 3, 193-210.

Ramon y Cajal, S. (1928). Degeneration \& Regeneration of the Nervous System. London: Oxford University Press.

Rasia-Filho, A. A., Fabian, C., Rigoti, K. M., and Achaval, M. (2004). Influence of sex, estrous cycle and motherhood on dendritic spine density in the rat medial amygdala revealed by the Golgi method. Neuroscience 126, 839-847.

Raymond, A. D., Kucherepa, N. N., Fisher, K. R., Halina, W. G., and Partlow, G. D. (2006). Neurogenesis of oxytocin-containing neurons in the paraventricular nucleus (PVN) of the female pig in 3 reproductive states: puberty gilts, adult gilts and lactating sows. Brain Res. 1102, 44-51.

Rochefort, C., Gheusi, G., Vincent, J. D., and Lledo, P. M. (2002). Enriched odor exposure increases the number of newborn neurons in the adult olfactory bulb and improves odor memory. J. Neurosci. 22, 2679-2689.

Rolls, A., Schori, H., London, A., and Schwartz, M. (2008). Decrease in hippocampal neurogenesis during pregnancy: a link to immunity. Mol. Psychiatry 13, 468-469.

Rosenblatt, J. S. (1967). Nonhormonal basis of maternal behavior in the rat. Science 156, 1512-1514.

Ruscio, M. G., Sweeny, T. D., Hazelton, J. L., Suppatkul, P., Boothe, E., and Carter, C. S. (2008). Pup exposure elicits hippocampal cell proliferation in the prairie vole. Behav. Brain Res. 187, 9-16.

Russell, J. A., Douglas, A. J., and Ingram, C. D. (2001). Brain preparations for maternity - adaptive changes in behavioral and neuroendocrine systems during pregnancy and lactation. An overview. Prog. Brain Res. 133, 1-38.

Sanchez, S., Pelaez, F., Gil-Burmann, C., and Kaumanns, W. (1999). Costs of infant-carrying in the cotton-top tamarin (Saguinus oedipus). Am. J. Primatol. 48, 99-111.

Schmechel, D. E., Brightman, M. W., and Marangos, P. J. (1980). Neurons switch from non-neuronal enolase to neuron-specific enolase during differentiation. Brain Res. 190, 195-214.

Scholzen, T., and Gerdes, J. (2000). The Ki-67 protein: from the known and the unknown. J. Cell. Physiol. 182, 311-322.

Seeringer, A., Walter, M., Kirchheiner, J., and Abler, B. (2010). Sex in the brain - imaging neural correlates of sexual stimulation. Nervenheilkunde 29, 468-474.

Seki, T., and Arai, Y. (1993). Highly polysialylated neural cell adhesion molecule (NCAM-H) is expressed by newly generated granule cells in the dentate gyrus of the adult rat. $J$. Neurosci. 13, 2351-2358.

Shaikh, A. A. (1971). Estrone and estradiol levels in the ovarian venous blood from rats during the estrous cycle and pregnancy. Biol. Reprod. 5, 297-307.

Shingo, T., Gregg, C., Enwere, E., Fujikawa, H., Hassam, R., Geary, C., Cross, J. C., and Weiss, S. (2003). Pregnancy-stimulated neurogenesis in the adult female forebrain mediated by prolactin. Science 299, 117-120.

Shors, T. J., Miesegaes, G., Beylin, A., Zhao, M., Rydel, T., and Gould, E. (2001). Neurogenesis in the adult is involved in the formation of trace memories. Nature 410, 372-376.

Sierra, A., Encinas, J. M., and MaleticSavatic, M. (2011). Adult human neurogenesis: from microscopy to magnetic resonance imaging. Front. Neurosci. 5:47. doi:10.3389/fnins.2011.00047

Silverstein, M., and Bengtson, V. L. (1991). Do close parent-child relations reduce the mortality risk of older parents? J. Health Soc. Behav. 32, 382-395.

Simon, M., Czeh, B., and Fuchs, E. (2005). Age-dependent susceptibility of adult hippocampal cell proliferation to chronic psychosocial stress. Brain Res. 1049, 244-248.

Sivan, E., Whittaker, P. G., Sinha, D., Homko, C. J., Lin, M., Reece, E. A., and Boden, G. (1998). Leptin in human pregnancy: the relationship with gestational hormones. Am. J. Obstet. Gynecol. 179, 1128-1132.

Smith, A. S., and Wang, Z. (2011). Salubrious effects of oxytocin on social stress-induced deficits. Horm. Behav. 61, 320-330.

Smith, M. T., Pencea, V., Wang, Z. Luskin, M. B., and Insel, T. R. (2001). Increased number of BrdU-labeled neurons in the rostral migratory stream of the estrous prairie vole. Horm. Behav. 39, 11-21.

Snyder, J. S., and Cameron, H. A. (2011). Could adult hippocampal neurogenesis be relevant for human behavior? Behav. Brain Res. 227, 384-390.

Spalding, K. L., Bhardwaj, R. D., Buchholz, B. A., Druid, H., and Frisen, J. (2005). Retrospective birth dating of cells in humans. Cell 122, 133-143.

Spritzer, M. D., and Galea, L. A. (2007). Testosterone and dihydrotestosterone, but not estradiol, enhance survival of new hippocampal neurons in adult male rats. Dev. Neurobiol. 67, 1321-1333.

Spritzer, M. D., Ibler, E., Inglis, W. and Curtis, M. G. (2011). Testosterone and social isolation influence adult neurogenesis in the dentate gyrus of male rats. Neuroscience 195 180-190.

Spritzer, M. D., Weinberg, A., Viau, V., and Galea, L. A. (2009). Prior sexual experience increases hippocampal cell proliferation and decreases risk assessment behavior in response to acute predator odor stress in the male rat. Behav. Brain Res. 200 106-112.

Staples, L. G. (2010). Predator odor avoidance as a rodent model of anxiety: learning-mediated consequences beyond the initial exposure. Neurobiol. Learn. Mem. 94, 435-445.

Steptoe, A. (1991). Invited review. The links between stress and illness. J. Psychosom. Res. 35, 633-644.

Stoeber, K., Tlsty, T. D., Happerfield, L., Thomas, G. A., Romanov, S., Bobrow, L., Williams, E. D., and Williams, G. H. (2001). DNA replication licensing and human cell proliferation. J. Cell Sci. 114, 2027-2041.

Stranahan, A. M., Khalil, D., and Gould, E. (2006). Social isolation delays the positive effects of running on adult neurogenesis. Nat. Neurosci. 9, 526-533.

Sung, Y. H., Shin, M. S., Cho, S., Baik, H. H., Jin, B. K., Chang, H. K., Lee, E. K., and Kim, C. J. (2010). Depression-like state in maternal rats induced by repeated separation of pups is accompanied by a decrease of cell proliferation and an increase of apoptosis in the hippocampus. Neurosci. Lett. 470, 86-90.

Tabori, N. E., Stewart, L. S., Znamensky, V., Romeo, R. D., Alves, S. E., Mcewen, B. S., and Milner, T. A. (2005). Ultrastructural evidence that androgen receptors are located at extranuclear sites in the rat hippocampal formation. Neuroscience 130, 151-163.

Tanapat, P., Hastings, N. B., and Gould, E. (2005). Ovarian steroids influence cell proliferation in the dentate gyrus of the adult female rat in a dose- and time-dependent manner. J. Comp. Neurol. 481, 252-265.

Tanapat, P., Hastings, N. B., Reeves, A. J., and Gould, E. (1999). Estrogen stimulates a transient increase in the number of new neurons in the dentate gyrus of the adult female rat. J. Neurosci. 19, 5792-5801.

Tanapat, P., Hastings, N. B., Rydel, T. A., Galea, L. A., and Gould, E. (2001). Exposure to fox odor inhibits cell proliferation in the hippocampus of adult rats via an adrenal hormone-dependent mechanism. J. Comp. Neurol. 437, 496-504.

Tashiro, A., Makino, H., and Gage, F. H. (2007). Experience-specific functional modification of the dentate gyrus through adult neurogenesis: a critical period during an immature stage. J. Neurosci. 27, 3252-3259.

Thomas, R. M., Hotsenpiller, G., and Peterson, D. A. (2007). Acute psychosocial stress reduces cell survival in adult hippocampal neurogenesis without altering proliferation. $J$. Neurosci. 27, 2734-2743.

Thomas, R. M., Urban, J. H., and Peterson, D. A. (2006). Acute exposure to predator odor elicits a robust increase in corticosterone and a decrease in activity without altering proliferation in the adult rat hippocampus. Exp. Neurol. 201, 308-315.

Tirindelli, R., Dibattista, M., Pifferi, S., and Menini, A. (2009). From pheromones to behavior. Physiol. Rev. 89, 921-956.

Townsend, K. C., and McWhirter, B. T. (2005). Connectedness: a review of the literature with implications 
for counseling, assessment, and research. J. Couns. Dev. 83, 191-201.

Tsigos, C., and Chrousos, G. P. (2002). Hypothalamic-pituitary-adrenal axis, neuroendocrine factors and stress. J. Psychosom. Res. 53, 865-871.

Turnbull, A. C., Patten, P. T., Flint, A. P., Keirse, M. J., Jeremy, J. Y., and Anderson, A. B. (1974). Significant fall in progesterone and rise in oestradiol levels in human peripheral plasma before onset of labour. Lancet 1, 101-103.

Valenstein, E. S., and Young, W. C. (1955). An experiential factor influencing the effectiveness of testosterone propionate in eliciting sexual behavior in male guinea pigs. Endocrinology 56, 173-177.

van Bokhoven, P., Oomen, C. A., Hoogendijk, W. J., Smit, A. B., Lucassen, P. J., and Spijker, S. (2011). Reduction in hippocampal neurogenesis after social defeat is longlasting and responsive to late antidepressant treatment. Eur. J. Neurosci. 33, 1833-1840.

van der Hart, M. G., Czeh, B., De Biurrun, G., Michaelis, T., Watanabe, T., Natt, O., Frahm, J., and Fuchs, E. (2002). Substance P receptor antagonist and clomipramine prevent stress-induced alterations in cerebral metabolites, cytogenesis in the dentate gyrus and hippocampal volume. Mol. Psychiatry 7, 933-941.

van Praag, H., Schinder, A. F., Christie, B. R., Toni, N., Palmer, T. D., and Gage, F. H. (2002). Functional neurogenesis in the adult hippocampus. Nature 415, 1030-1034. van Praag, H., Shubert, T., Zhao, C., and Gage, F. H. (2005). Exercise enhances learning and hippocampal neurogenesis in aged mice. J. Neurosci. 25 8680-8685.

Veenema, A. H., and Neumann, I. D. (2008). "Central vasopressin and oxytocin release: regulation of complex social behaviours," in Advances in Vasopressin and Oxytocin: From Genes to Behaviour to Disease, eds I. J. A. Urban, J. P. H. Burbach, and D. De Wied (Amsterdam: Elsevier Science Bv), 261-276.

Waldherr, M., and Neumann, I. D. (2007). Centrally released oxytocin mediates mating-induced anxiolysis in male rats. Proc. Natl. Acad. Sci. U.S.A. 104, 16681-16684.

Wallace, K. J., and Rosen, J. B. (2000). Predator odor as an unconditioned fear stimulus in rats: elicitation of freezing by trimethylthiazoline, a component of fox feces. Behav. Neurosci. 114, 912-922.

Waltz, M., Badura, B., Pfaff, H., and Schott, T. (1988). Marriage and the psychological consequences of a heart attack: a longitudinal study of adaptation to chronic illness after 3 years. Soc. Sci. Med. 27, 149-158.

Wang, C., Liu, F., Liu, Y. Y., Zhao, C. H., You, Y., Wang, L., Zhang, J., Wei, B., Ma, T., Zhang, Q., Zhang, Y., Chen, R., Song, H., and Yang, Z. (2011). Identification and characterization of neuroblasts in the subventricular zone and rostral migratory stream of the adult human brain. Cell Res. 21, 1534-1550.

Weickert, C. S., Webster, M. J., Colvin, S. M., Herman, M. M., Hyde, T. M.,
Weinberger, D. R., and Kleinman, J. E. (2000). Localization of epidermal growth factor receptors and putative neuroblasts in human subependymal zone. J. Comp. Neurol. 423, 359-372.

Weiland, N. G., Orikasa, C., Hayashi, S., and Mcewen, B. S. (1997). Distribution and hormone regulation of estrogen receptor immunoreactive cells in the hippocampus of male and female rats. J. Comp. Neurol.388 603-612.

Westenbroek, C., Den Boer, J. A., Veenhuis, M., and Ter Horst, G. J. (2004). Chronic stress and social housing differentially affect neurogenesis in male and female rats. Brain Res. Bull. 64, 303-308.

Williams, J. R., Catania, K. C., and Carter, C. S. (1992). Development of partner preferences in female prairie voles (Microtus ochrogaster): the role of social and sexual experience. Horm. Behav. 26, 339-349.

Winberg, J. (2005). Mother and newborn baby: mutual regulation of physiology and behavior - a selective review. Dev. Psychobiol. 47, 217-229.

Winner, B., Kohl, Z., and Gage, F. H. (2011). Neurodegenerative disease and adult neurogenesis. Eur. J. Neurosci. 33, 1139-1151.

Wong, E. Y., and Herbert, J. (2005). Roles of mineralocorticoid and glucocorticoid receptors in the regulation of progenitor proliferation in the adult hippocampus. Eur. J. Neurosci. 22, 785-792.

Yap, J. J., Takase, L. F., Kochman, L. J. Fornal, C. A., Miczek, K. A., and Jacobs, B. L. (2006). Repeated brief social defeat episodes in mice: effects on cell proliferation in the dentate gyrus. Behav. Brain Res. 172 344-350.

Young, K. A., Gobrogge, K. L., Liu, Y. and Wang, Z. (2011). The neurobiology of pair bonding: insights from a socially monogamous rodent. Front. Neuroendocrinol. 32, 53-69.

Young, L. J., and Wang, Z. (2004). The neurobiology of pair bonding. Nat. Neurosci. 7, 1048-1054.

Zheng, W., Zhuge, Q., Zhong, M., Chen, G., Shao, B., Wang, H., Mao, X., Xie, L., and Jin, K. (2011). Neurogenesis in adult human brain after traumatic brain injury. J. Neurotrauma. doi:10.1212/s00222-009-0987-6

Conflict of Interest Statement: The authors declare that the research was conducted in the absence of any commercial or financial relationships that could be construed as a potential conflict of interest.

Received: 30 January 2012; accepted: 16 April 2012; published online: 08 May 2012.

Citation: Lieberwirth $C$ and Wang $Z$ (2012) The social environment and neurogenesis in the adult mammalian brain. Front. Hum. Neurosci. 6:118. doi: 10.3389/fnhum.2012.00118

Copyright (c) 2012 Lieberwirth and Wang. This is an open-access article distributed under the terms of the Creative Commons Attribution Non Commercial License, which permits noncommercial use, distribution, and reproduction in other forums, provided the original authors and source are credited. 